NBER WORKING PAPER SERIES

IS A VC PARTNERSHIP GREATER THAN THE SUM OF ITS PARTNERS?

\author{
Michael Ewens \\ Matthew Rhodes-Kropf \\ Working Paper 19120 \\ http://www.nber.org/papers/w19120
}

\author{
NATIONAL BUREAU OF ECONOMIC RESEARCH \\ 1050 Massachusetts Avenue \\ Cambridge, MA 02138 \\ June 2013
}

We thank Viral Acharya, Joan Farre-Mensa, Thomas Hellmann, Bill Kerr, Josh Lerner, Ramana Nanda, David Robinson, Merih Sevilir and Morten Sorensen for fruitful discussion and comments as well as participants at the American Finance Association meetings, Fed/NYU Conferences on Private Equity, Washington University 9th Annual Corporate Finance Conference, Stanford / JOIM Private Equity conference, Jackson Hole Finance Group conference, Harvard University, as well as Correlation Ventures and VentureSource for access to the data. Both authors are advisors to, and investors in Correlation Ventures. All errors are our own. The views expressed herein are those of the authors and do not necessarily reflect the views of the National Bureau of Economic Research.

NBER working papers are circulated for discussion and comment purposes. They have not been peerreviewed or been subject to the review by the NBER Board of Directors that accompanies official NBER publications.

(C) 2013 by Michael Ewens and Matthew Rhodes-Kropf. All rights reserved. Short sections of text, not to exceed two paragraphs, may be quoted without explicit permission provided that full credit, including $\odot$ notice, is given to the source. 
Is a VC Partnership Greater than the Sum of its Partners?

Michael Ewens and Matthew Rhodes-Kropf

NBER Working Paper No. 19120

June 2013

JEL No. G24,G30,G32,L26

\title{
ABSTRACT
}

This paper investigates whether individual venture capitalists have repeatable investment skill and to what extent their skill is impacted by the VC firm where they work. We examine a unique dataset that tracks the performance of individual venture capitalists' investments across time and as they move between firms. We find evidence of skill and exit style differences even among venture partners investing at the same VC firm at the same time. Furthermore, our estimates suggest the partner's human capital is two to five times more important than the VC firm's organizational capital in explaining performance.

\author{
Michael Ewens \\ Carnegie Mellon University \\ Tepper School of Business \\ 5000 Forbes Ave \\ Pittsburgh, PA 15213 \\ mewens@cmu.edu \\ Matthew Rhodes-Kropf \\ Harvard Business School \\ Rock Center 313 \\ Soldiers Field \\ Boston, MA 02163 \\ and NBER \\ mrhodeskropf@hbs.edu
}


Venture capital investments are an important engine of innovation and economic growth, but extremely risky from an individual investor's point of view. Sahlman (2010) reports that $85 \%$ of returns come from just 10\% of investments. And from 1987 until 2012 only $12.8 \%$ of investments have achieved an initial public offering. ${ }^{1}$ Furthermore, there are large differences in fund performance between top quartile and bottom quartile venture capital funds. In spite of the rarity of top investments, Kaplan and Schoar (2005) report persistence in fund performance. They show that in contrast to other asset classes such as mutual funds, venture capital firms that have a fund that outperforms the industry are likely to outperform with their next fund.

The ability to consistently produce top performing investments implies that there is something unique and time-invariant about venture capital firms. For example, deal flow (Sorensen (2007)) and networks (Hochberg, Ljungqvist and Lu (2007)) have been shown to explain much of the cross section of VC fund performance. Hellmann and Puri (2002) report that higher quality VC's have industry experience and Gompers, Kovner and Lerner (2009) find that VC parter specialization can explain cross-sectional differences in performance. There could also be firm policies or complementarities among partners or other attributes that allow consistent top performance.

However, it is an unanswered question as to what extent the important attributes of performance are a part of the VC firm's organizational capital or embodied in the human capital of the people inside the VC firm. An extreme possibility is that attributes are embedded in the firm and the people are substitutable, or alternatively a venture firm is simply a collection of people.

\footnotetext{
${ }^{1} 12.8 \%$ of the investments included in the Venture Source database can be found to have eventually completed an initial public offering.
} 
An analogy to universities, another human capital intensive environment we all know well, will provide insight. The question we explore is similar to asking to what extent an academic performs better at a top institution or are top institutions just collections of top academics. The greater resources, reduced teaching, better students, better colleagues, etc. of top institutions could make any researcher more productive. This scenario implies a large effect from organizational capital. Alternatively, better research could come from human capital differences, implying that researchers would perform equally well at any school.

In venture capital firms, features such as brand, resources, reputation, firm deal flow, firm network, investment processes, better colleagues, etc. could all help a partner perform better. Alternatively, an individual might have a reputation, network, deal flow and a great ability to find, identify or make investments. Furthermore, just as university quality may be more important to researchers who did particular types of research, the firm may be more important to investors involved in IPOs rather than acquisitions. We examine both of these questions.

Shedding light on the sources of performance in venture capital firms will help us make progress on a fundamental question in economics as to whether a firm is more than the sum of its parts. Williamson and Winter (1993) credit Klein (1988) with distinguishing physical from human asset specificity. They note that Klein (1988), in a response to Coase (1988), lecture 3, was the first to argue that an "organization is embedded in the human capital of the employees at" the firm, but is "greater than the sum of its parts. The employees come and go but the organization maintains the memory of past trials and the knowledge of how to best do something." (p. 220) Under this hypothesis, the venture firm holds some of the knowledge of how to make great investments.

Hart (1989) argues that "the observation that the whole of organizational capital is typi- 
cally greater than the sum of its parts is equivalent to the observation that the total output of a group of workers typically exceeds the sum of the workers' individual outputs, to the extent that there are complementarities." (p. 1772) Complementarities would imply that partners should match on quality and thus firms should contain partners of similar ability (see Becker (1981), Kremer (1993), Burdett and Coles (1997) and Shimer and Smith (2000) for work on complementarities and matching).

Venture capital provides an opportunity to study these questions because we can assign individual investments to partners and follow the latter across time as they move between firms. This structure invites an analysis of the relative importance of partners and firms in performance, although focusing only on venture capital limits the generality of our results.

We begin by examining persistence at the individual partner-investment level. We use the VentureSource database of venture capital investments in entrepreneurial firms founded between 1987-2005 (to allow time to observe outcomes) augmented with hand collected data. We find evidence of venture partner skill. For example, controlling for observable firm, partner and investment characteristics such as time, industry, dollars invested, VC experience, investment round number, firm founding date, etc., we find that among investors who made at least three investments, a one standard deviation increase in past IPO rate implies a $18 \%$ higher probability of an IPO in their third investment. ${ }^{2}$ Given the rarity of IPOs, the strength of persistence at the partner-investment level is quite high, particularly in light of recent work by Phalippou (2010) that argues that ex-ante persistence comes only from low performance and the Kaplan and Schoar (2005) results are exaggerated. Our ability to find strong persistence in IPOs, even with numerous deal and partner level controls

\footnotetext{
${ }^{2}$ In a complementary paper, Gompers et al. (2010) address whether the entrepreneurs receiving VC have performance persistence. They find an explanation for the source of persistence, while we attempt to separate the importance of the firm and person in outcomes.
} 
not before possible, provides support for Kaplan and Schoar (2005)'s original fund level persistence results as well as recent work on fund persistence by Hochberg, Ljungqvist and Vissing-Jorgensen (2012) and Harris et al. (2013).

We also investigate persistence in other types of exits. On average, the same people who have IPO'd will continue to IPO, those who achieve top exits through M\&A will continue to do so and those who fail will continue to fail. Overall it seems that partners have exit "styles" insofar as they make investments that tend to exit in the same way. ${ }^{3}$

Next, we include the past performance of the firm by the other partners to begin to study the role of the firm in partner performance persistence. We find that a firm's past IPO success rate also correlates with a partner's probability of achieving an IPO on his next investment. But, of course, we cannot tell if this is because similar quality partners join together to form a firm (as implied by assortative matching), in which case past firm performance is just more information about partner quality, or if better firms make it more likely that a partner will IPO.

When we include VC firm cohort fixed effects, we still find significant persistence. That is, even comparing partners in the same firm investing at the same time, we find persistence in their relative ability to IPO or achieve top M\&A exits. This finding demonstrates the strength of the persistence. Assortative matching should have driven like quality partners to join together, but on average venture capital firms do not seem to be collections of similar quality partners.

Results from looking directly at the average persistence of venture capital partners highlights the potential importance of the partner and the firm but cannot tell us their relative

\footnotetext{
${ }^{3}$ Venture partners determine which deals they want to do and then seek approval from their partners. They are not assigned deals, nor do they have to give deals they like to other partners. Deals are typically passed between partners if the partner who finds the deals does not feel he has the time or expertise to investigate or manage the deal. Thus this style persistence seems to be a quality of the VC partner.
} 
importance. In order to separate the firm and partner, we exploit partner movement between firms. To the extent that partners change performance as they move firms, "ability" will be allocated to the firm from complementarities, policies, brand, etc. And to the extent the moving partners do not alter their own or their co-partners' performance, "ability" will be allocated to the partner.

Bertrand and Schoar (2003) employ a similar idea when they examine CEOs who move firms and separate out manager effects on firm policies, while Graham, Li and Qiu (2012) use executives who move to determine the relative importance of firm and person in executive compensation. We employ the method developed by Abowd, Kramarz and Margolis (1999) (hence forth AKM) and Abowd, Creecy and Kramarz (2002) to separate out partner and firm effects on the performance of venture capital investments. ${ }^{4}$

Estimates of the VC partner and firm fixed effects provide evidence of the relative importance of VC partner human capital and VC firm organizational capital. Across different specifications we find that the partner fixed effects are more likely to be jointly significant than the VC firm fixed effects and that the partner fixed effect estimates explain two to five times the variation in exit values relative to VC firm fixed effects. Thus, our estimates suggest that both the partner and the VC firm can affect performance but that the partner's human capital is more important. The estimates of partner fixed effects also demonstrate significant heterogeneity in partner type. Translated into level of exit valuation, the distribution of partner fixed effects implies that top quartile partners produce at least $\$ 82 \mathrm{~m}$ on average in exit valuation, while bottom quartile partners produce less than $\$ 4 \mathrm{~m}$. To put this in context, the mean exit value is $\$ 151 \mathrm{~m}$ and the median is zero. The strong partner fixed effects

\footnotetext{
${ }^{4}$ Ertugrul and Krishnan (2011) use the AKM method to ask whether investment bankers matter for merger and acquisition outcomes.
} 
supports further study of individual partner characteristics (see Zarutskie (2010), Bottazzi, Da Rin and Hellmann (2008), and Acharya and Kehoe (Forthcoming)), such as gender, education, networks or experience, to better understand outcomes in venture capital.

The use of movers in this part of the analysis clearly restricts our sample to partners at firms where someone transferred to or away from the firm. The excluded sample covers $40 \%$ of VC firms who are less active and smaller. The included sample represents the active and central part of the venture capital community as it covers $74 \%$ of venture-backed investments.

The use of movers also introduces the concern that endogenous moving affects our results. In our final sample, over $30 \%$ of partners change firms and thus provide ample data on movement. However, our findings only tell us the average effect of movement on partners who move. To what extent partners who do not move would be similarly affected is unknown. As in all papers that use movement as an identification strategy, some endogeneity concerns cannot be eliminated. What we can do is consider the probable impacts from endogenous movement as well as examine different subsamples and controls to address empirical concerns.

Recall that the estimation technique uses changes in performance of movers' investment around the move to identify the firm fixed effects. We separately look at partners who move to historically worse performing firms compared to those who move to historically better performing firms. Movers to better firms are more likely choosing to move and doing so in anticipation of changes to their performance. We also consider partners who move to very different firms versus partners who move to similar firms. In all cases, the conclusions about the relative value of the firm are similar. Despite these and other attempts to deal with endogeneity we acknowledge that we cannot completely eliminate the issue, and thus our 
results must be interpreted with some caution.

The balance of the paper is organized as follows. First, we explore the data and variables of interest. This is presented in Section I. Next, we study persistence at the partner-level across a range of outcomes. This is presented in Section II. Section III presents estimation of a full fixed effects model. Then, in Sections IV and V we present sub-sample and robustness results for all estimates. Section VI concludes.

\section{Data description}

The main dataset begins with the venture capital financings, investors and entrepreneurial firms from data provider VentureSource. Using quarterly surveys, press releases and regulatory filings, VentureSource provides a comprehensive picture of the venture capital market. The full database covers 1987 to 2012 and includes 27,079 financings in 16,897 entrepreneurial firms financed by 3,777 investing firms. We improve the data on two fronts with information provided confidentially by several venture capital firms, limited partners, web searches and public data sources. ${ }^{5}$ First, the set of exit or investment valuations - more often missing in similar databases - was improved for a larger set of acquisitions and public offerings. This was done through searches of S-1 filings, a merge of VentureSource with SDC's M\&A data and relationships with some VC firms. We believe the resulting exit valuations are more representative of exits than the standard data sources.

Next, a collection of web searches of venture capital firm websites, Capital IQ biography data and consistency checks from other pieces of data within VentureSource each identify where VC partners in VentureSource worked when they made their investments. This also

\footnotetext{
${ }^{5}$ We thank Correlation Ventures for allowing us to use the extensive data they have collected on historical investments, partners and outcomes. Correlation Ventures is a venture capital fund that uses quantitative methods for investment selection. As such, they are attempting to build a comprehensive set of historical venture deals and outcomes.
} 
ensures that we separately identify partners with the same name. The resulting database covers the employment history of venture capital partners from 1987 - present. We validated a large, random pool of board seats using VentureXpert and "Form D" regulatory filings. The latter are the required filings of sales of private securities that report amounts invested and directors (i.e. VC board members). The analysis found no systematic errors and revealed we have a comprehensive dataset of venture partner investments.

The panel of venture capital partner board members covers 1987 to 2012 where a board member is any investor listed on an entrepreneurial board and associated with a venture capital or other investing firm. This definition excludes outside board members or any of the management team of the entrepreneurial firm. We only include board members in the data that have at least two entrepreneurial board seats for firms founded prior to 2006 and whose investing firm has made at least four investments over the whole sample. The latter restriction eliminates small VCs, those that rarely take board seats and many corporate venture capitalists. The major sample includes 19,031 financings, 11,885 entrepreneurial firms, 1,573 investing firms and 5,324 unique VC partners. ${ }^{6}$ The average board member has 6 board seats (median 4$)$.

Venture capital partners who switch venture capital firms are an important part of our analysis. After correcting the data on board membership that matches partners to board seats, we can track movement of individuals between VC firms. We label a mover as a venture capital partner with multiple board seats assigned to different VC firms. Analyzing the change in titles for the first moves of all movers shows that the vast majority are promoted or remain at the same level. In particular, $45 \%$ of movers start as general partners (GP),

\footnotetext{
${ }^{6}$ We define anyone who invests in two venture financing where they sit on the board as a 'VC' although some may work for a firm that also does more later stage investing in more established firms (often referred to as a PE firm), and some may be individual, so called 'angel' investors.
} 
with $76 \%$ moving up to managing director or remaining as a GP. Similarly, only $27 \%$ of the movers who start as managing directors appear to be demoted after their first move. ${ }^{7}$ Section III provides additional information about movers including the firms they move to and from and a comparison of non-movers.

There are several dependent variables of interest that we use throughout the analysis. ${ }^{8}$ We initially follow the literature and characterize success by whether the entrepreneurial firm had an initial public offering. Some $12.8 \%$ of entrepreneurial firms in the sample and $10 \%$ of board seats had such an exit (i.e. some entrepreneurial firms have multiple observations because there are multiple board seats). The IPO dependent variable is a weaker measure of success since 2002 as $90 \%$ of non-failure exits were acquisitions.

We also consider success through acquisitions. We create a dummy variable for "successful acquisition" which is 1 if the entrepreneurial firm sold via a merger or acquisition at a value at least twice the total capital invested. We cannot determine actual returns for acquisitions because we do not know the amount returned to the VC at exit, but if the total sale value was more than twice the amount invested, then it is likely to be a more successful exit on average than exits with a smaller exit value to investment ratio. ${ }^{9}$ We also cannot use all acquisition outcomes because some do not report a value and many appear to be disguised failures. However, the largest acquisitions (greatest successes) tend to have reported values because the acquisition is material to the public acquirer and thus required to be disclosed.

Combining IPOs and "successful acquisitions" the fraction of success is $23 \%$ for entrepreneurial firms and $21 \%$ for board seats. Along with these two success variables, a dummy variable "Failure" is set to 1 if the firm shutdown, is still private by the end of the sample

\footnotetext{
${ }^{7}$ The full analysis of title changes can be found in the online appendix.

${ }^{8}$ All outcomes are measured as of the end of 2012.

${ }^{9}$ Note that this variable is zero for initial public offerings. The results are insensitive to defining "successful" as $1.5-3 X$ of total capital raised.
} 
(through 2012), or had a low acquisition (less than twice total capital invested). In total there are 6 possibilities for an investment in our sample: IPO, successful acquisition, low acquisition, no-reported-value acquisition, failure, or still private. As a final measure, we summarize all outcomes into one variable using the log of one plus the exit value - zero for failures combined with IPO and reported acquisition values. Since some firms have yet to exit or have a missing exit valuations, we deal with these firms in two ways. For our main analysis we treat them as zeros but we also drop them from the sample and find similar results. ${ }^{10}$ Table I details these dependent variables and a host of controls that we use through the analysis.

\section{Results: VC Partner Performance Persistence}

When a venture capital firm makes an investment in an entrepreneurial firm, the partner who led the investment at the venture capital firm often takes a seat on the board. For each of these events, we calculate the venture capital partner's investment history. “\% IPO $t-1$ " measures the fraction of the partner's investments made prior to $t$ that exited via an initial public offering. Performance persistence implies that past performance has predictive power for future outcomes. Our analysis of persistence tracks the relationship between a partner's investment success and the outcome of the current board seat investment $\left(\mathrm{IPO}_{t}\right)$. Thus, we ask whether or not venture capital partners who have made more investments that IPO'd in the past are more likely to IPO their current investment.

Attrition in the data may lead to a spurious relationship between past success and future outcomes. The null hypothesis of no persistence implies that each new investment is

\footnotetext{
${ }^{10}$ Firms that have not exited are often thought to be the living dead and firms that don't report exit values tend to have smaller exits. Our cutoff of founding dates pre-2006 implies the entrepreneurial firms have 6 years to exit. This suggests we should treat them as zeros.
} 
a random draw. Presumably worse performing investors are more likely to leave the sample. If this is true, then under the null, the majority of active partners in the data would be lucky, unskilled investors. Here, naively examining the data would result in a finding of positive persistence. However, if we looked only at investors who did at least $t$ investments then these investors' past success would have no correlation with the outcome of their next investment.

The following regressions only consider cross-sections within the set of partners with $t$ investments. That is, we ask whether partners with at least three (or 5 or 7 ) investments and a greater fraction of IPOs in their first two (or 4 or 6 ) investments are more likely to IPO their third (or fifth or seventh) investment. Our results will therefore be the persistence conditional on having a level of partner experience in number of investments. ${ }^{11}$

Before reporting regression results we note that the probability that a partner's second investment IPOs is unconditionally $12.5 \%$. However, conditional on the first investment IPOing the probability of the second IPOing is $35 \%$, while conditional on the first investment not IPOing the probability of the second IPOing is $8 \%$. This same persistence is found formally in the regressions below.

Table II reports the results of a probit regression on cross-sections of partner experience for the second, third, fifth and seventh investment. Controls include the age of the VC firm, the time the VC has been taking board seats and entrepreneurial firm characteristics such as industry ("Information Technology," "Healthcare," “Consumer/Retail," and “Other”), investment year, dollars invested and development stage (round number fixed effects), with

\footnotetext{
${ }^{11}$ As we condition on investors with more and more investments this is not a random sample of investors. The estimates of persistence we find are conditional on making $t$ investments. They are not the average amount of skill but the relative skill among investors with $t$ investments. The online appendix provides the results from a regression that pools all the experience levels.
} 
standard errors are clustered at the investment year. ${ }^{12}$ The estimates imply a strong relationship between a partner's earlier investment outcomes and current success. ${ }^{13}$ A one standard deviation increase in the the fraction of IPOs for investments made prior to $t$ implies a $18 \%, 15 \%$ and $18 \%$ increase in the predicted IPO probability for investments 3,5 and 7 respectively (where one standard deviation is $29 \%, 24 \%$, and $21 \%$ respectively). The signs on the coefficients for the major control variables are as expected, although the estimate for "Log years partner experience" merits discussion. Each sub-sample conditions on experience, so the interpretation of this control is the relative speed at which a partner gets to $t$ investments. The negative coefficient in some specifications implies that partners that take longer to get to that $t$ 'th investment are relatively less likely to have a subsequent IPO.

Note that the coefficient on persistence is from a comparison with other investors who made the same number of investments. It would seem that skill might differentiate partners as they start their career, but attrition could reduce the sample to only the group of more and more skilled partners. This would result in narrower, or possibly no, skill differences in the most experienced group. Simultaneously, as we move to partners with a greater number of investments we have more data about the partner, and thus presumably more accurate estimates of partner quality. Overall, although each subsample is possibly quite different, we find significant skill differences at each experience level.

Note also that we use the eventual outcome of the earlier investments even if the exit has not yet occurred by the $t^{\prime}$ th investment. This is because we are not asking if the quality of the VC was in the public information set but only whether VCs who invest in eventual IPOs are more likely to produce an IPO with their next investment. In unreported results, we also

\footnotetext{
${ }^{12}$ We also use a 17 industry classification as well as a 115 industry classification with similar results.

${ }^{13}$ Phalippou (2010) argues that fund-level persistence is non-existent or mainly driven by the left tail. Our results support the original Kaplan and Schoar (2005) persistence result as partner level persistence should lead to fund persistence unless fees are adjusted to match skill (something rarely done in VC).
} 
repeat the analysis in Table II with "public IPO" or the fraction of board seats with known success as of the current board seat. The results are similar. ${ }^{14}$ So knowledge about initial success at the time of the next investment does not measurably affect the quality of the next investment. This result is evidence against the idea that persistence comes from initial luck which provides a "halo" that makes it easier to access future good investments.

\section{A. Alternative outcome measures}

While the IPO is an accepted measure of partner and VC firm success, there is a large range of other outcome variables for entrepreneurial investments. Consider the three additional outcome variables discussed above: successful acquisition, failure and exit valuation. For each, we create an analogue to “\% IPO $t-1$ ” that summarizes a partner's fraction of success or failure. "\% Acq. $t-1$ " is the fraction of the partner's investments made prior to $t$ that had a successful acquisition. “\% Fail $t-1$ ” measures the same, but uses investment failure. Finally, "Avg. Exit value $t-1$ " uses the average of one plus the exit value of all investments made prior to $t$ (logged).

Columns 1 and 3 of Table III again show a strong correlation between the success (or failure) of earlier investments and future outcomes. Recall that a one standard deviation increase in IPO at investment three implies a $18 \%$ increase in future success probability. The predicted impacts for a one standard deviation increase in historical successful acquisitions or failures at investment three is $10 \%$ and $8 \%$ respectively. For the fifth investment these magnitudes are 15\% (IPO), 10\% (Acquisition) and 6\% (failure). The analogous predictions for a one standard deviation increase in historical exit value at investments three and five

\footnotetext{
${ }^{14} \mathrm{Also}$ in unreported regression, we introduce a longer history to the persistence regressions such as the partner's IPO rate as of two investments previous $\left(\mathrm{IPO}_{t-2}\right)$. Longer lags remain statistically significant, while the size falls as we go further back in the partner's investment history.
} 
are $13 \%$ and $14 \%$.

The results show that additional controls and measures of quality further our understanding of partner performance persistence. Persistence in returns is not simply at the portfolio level, but also investment by investment at the partner-level for IPOs, high acquisition exits and failure, even controlling for partner, firm, industry and time-varying characteristics in a way that was not possible in other work. Overall, partners seem to have an exit "style." 15

\section{B. Persistence and the VC firm}

Does the persistence found above stem from the partner or the firm where the partner works? For example, VC partners could simply match to high quality firms and inherit the firm's deal flow and resources (e.g. Sorensen (2007)). To begin to address this, we include the past performance of the other partners in the firm. Define "\%VC IPO $(-i)$ " as the fraction of board seats for the partner's VC firm that had an IPO excluding those investments made by the partner. If a partner is merely successful because of the firm, then the inclusion of this control should eliminate or at least dramatically lower the coefficient on the partner's past success. The last four columns of Table II introduce this control. The inclusion of the other partner VC performance does not alter the explanatory power of the partner's past investment success. In fact, both measures are statistically meaningful in nearly all specifications. The evidence suggests that both the partner and the firm play a role in investment outcomes, but additional analysis is required to separate the two. We next introduce a venture capital fund fixed effect to compare partners in the same firm investing at the same time.

\footnotetext{
${ }^{15}$ This result echo's findings in a recent working paper Smith, Pedace and Sathe (2010) that reports that funds that have a high percentage of IPOs or M\&A exits tend to have a higher percentage in their next fund.
} 


\section{VC fund fixed effects}

Venture capital firms are potentially long-lived and each firm raises a new fund to invest typically every few years. Partners, as well as the size of funds, can change. To compare partners at the same firm investing at the same time we would like include fund fixed effects. Lacking a comprehensive mapping of fund to board seat, we create an alternative VC fund fixed effect. For each VC firm in the sample, we create "cohorts" of active VC partners by five-year windows. Starting from the first investment made by the VC firm, each five years creates a new firm cohort.

Table IV presents VC cohort fixed effect results for each of the exit outcomes from Table III using a conditional logit framework. This estimation compares partners investing at the same firm in the same time period. Estimates show that the success of earlier investments as measured by either IPO or successful acquisition predicts higher probabilities of such events in the future for IPOs and successful acquisitions. The results for failure persistence are weaker and statistically insignificant, while the exit value results in columns 7 and 8 remain strong. The results demonstrate both that the partner matters and that assortative matching among partners is significantly less than perfect - partners at the same firms have observably different abilities.

Altogether our findings suggest that persistence does not arise simply because funds tend to do the same type of investments at similar times. Rather, it seems due to real partner skill.

\section{Three-way fixed effects model}

The results in Table II indicate that both the venture capital firm and partner are important variables in the cross-section of outcomes. The results in Tables II or IV which include historical firm performance or VC fund fixed effects have two interpretations. One, VC firm 
characteristics explain part of the partner performance persistence. Or alternatively, partners with significant skill match together with similar (but not perfectly similar) partners. Separating the firm and partner in investment outcomes requires moving away from a study of persistence to a general cross-section analysis with fixed effects for both actors.

Consider the following linear model of exit valuation $V_{i j k t}$ :

$$
V_{i j k t}=\beta_{1} X_{i t}+\beta_{2} Z_{j t}+\beta_{3} U_{k t}+\alpha_{i}+\phi_{j}+\gamma_{t}+\epsilon_{i j k t}
$$

In equation (1), $i$ denotes the VC partner, $j$ the VC firm, $k$ the entrepreneurial firm and $t$ the date of the investment. $\gamma_{t}$ is the investment year fixed effect. The variables $X_{i t}, Z_{j t}$ and $U_{k t}$ include time-varying controls for each. The unit of observation a board seat taken by a venture capital partner $i$ in entrepreneurial firm $k$ while working at VC firm $j$. The date $t$ is defined by the first investment made by VC firm $j$ in firm $k$. Our focus is the retrieval of the partner and firm fixed effects $\alpha_{i}$ and $\phi_{j}$, which requires movements of partners between firms.

Bertrand and Schoar (2003) use movers within a sample of CEOs to identify whether individual fixed effects can explain cross-sectional variation in corporate policy variables. We use the Abowd, Kramarz and Margolis (1999) (AKM) refinement of this methodology developed further in Abowd, Creecy and Kramarz (2002). AKM is a part of a large literature in labor economics that attempts to isolate sources that are statistically related to employment compensation. Graham, Li and Qiu (2012) use this refinement to examine the impact of the firm and individual on executive compensation. The AKM method provides estimates of firm and partner fixed effects for both movers and stayers. The inclusion of fixed effects for all partners and firms results in a potentially large set of parameter estimates, typically re- 
duced by transforming the data using the within estimator. This transformation demeans by one of the fixed effect dimensions. AKM show that this approach does not simultaneously address the heterogeneity and allow parameter recovery. They show that including firm fixed effects after first sweeping out partner heterogeneity produces the standard result from a dummy variable regression. As in the Bertrand and Schoar (2003) study, one also has to define the sample in which fixed effects can be estimated, theirs being the mobility sample of CEOs. The analogous group in the AKM method is the "connected" group.

Detailed by by Abowd, Creecy and Kramarz (2002), the “connectedness” sample provides the set of firms and partners that can be identified with the AKM method. Graph theory is used to determine groups of individuals that are connected. Moreover, Abowd, Creecy and Kramarz (2002) provides the normalization procedure to ensure that the fixed effect estimates are comparable in the whole sample.

The connectedness sample requires some partners to be employed by multiple firms. Any two firms are connected if a partner moves from one to the other and any string of firms is connected if they are connected to a firm that is connected to another firm. For example, if a partner from firm A moved to firm B and another partner moved from firm B to firm $\mathrm{C}$ then $\mathrm{A}, \mathrm{B}$, and $\mathrm{C}$ are connected. If another partner moved from firm $\mathrm{D}$ to $\mathrm{A}, \mathrm{B}$, or C then A, B, C, and D are all connected. Abowd, Creecy and Kramarz (2002) show that connections invite computationally feasible estimation of the firm and person fixed effects for each connected group, relative to a within-group benchmark. The benefit of this method is the ability to estimate the partner fixed effects for both movers and non-movers. Such a set is more representative if movers are very different on both observables and unobservables. ${ }^{16}$

${ }^{16}$ The analysis of managerial compensation in Graham, Li and Qiu (2012) has more detail on the methodology, its strengths and its limitations. 
It is useful to understand the basic features of how the AKM method separately identifies the partner and firm effect using the movers. ${ }^{17}$ Define the variable $F_{i l t}$ as a dummy variable equal to one if partner $i$ works at firm $l$ at time $t$, and zero otherwise. We can rewrite equations (1) as:

$$
V_{i j k t}=\beta_{1} X_{i t}+\beta_{2} Z_{j t}+\beta_{3} U_{k t}+\alpha_{i}+\sum_{l=1}^{J} F_{i l t} \phi_{l}+\gamma_{t}+\epsilon_{i j k t} .
$$

The AKM method first sweeps out the partner fixed effect by averaging over the partner's investments to get:

$$
\bar{V}_{i}=\beta_{1} \bar{X}_{i}+\beta_{2} \bar{Z}_{i}+\beta_{3} \bar{U}_{i}+\sum_{l=1}^{J} \bar{F}_{i l} \phi_{l}+\alpha_{i}+\bar{\gamma}_{t}+\bar{\epsilon}_{i}
$$

Here, $\bar{V}_{i}$ is partner i's average exit valuation across the whole sample period. Next, demean (2) with (3) to get:

$$
\begin{aligned}
V_{i j k t}-\bar{V}_{i}= & \beta_{1}\left(X_{i t}-\bar{X}_{i}\right)+\beta_{2}\left(Z_{j t}-\bar{Z}_{i}\right)+\beta_{3}\left(U_{k t}-\bar{U}_{i}\right) \\
& +\sum_{l=1}^{J}\left(F_{i l t}-\bar{F}_{i l}\right) \phi_{l}+\left(\gamma_{t}-\bar{\gamma}_{t}\right)+\left(\epsilon_{i j k t}-\bar{\epsilon}_{i}\right) .
\end{aligned}
$$

First note that the partner fixed effects have been removed with demeaning. Second, the term $\left(F_{i l t}-\bar{F}_{i l}\right) \phi_{l}$ makes clear that the VC firm fixed effect is only identified using partners that move (i.e. $F_{i l t} \neq \bar{F}_{i l}$ ). Analogous to the description in Graham, Li and Qiu (2012), the differences in performance for partners changing VC firms allow us to estimate the firm fixed effects for the firms where the mover was a partner.

Finally, we can recover the partner fixed effects using the estimates from the standard

${ }^{17}$ This discussion follows Graham, Li and Qiu (2012). 
least square dummy variable regression in (4) and the following equation:

$$
\hat{\alpha}_{i}=\bar{V}_{i}-\hat{\beta}_{1} \bar{X}_{i}-\hat{\beta}_{2} \bar{Z}_{i}-\hat{\beta}_{3} \bar{U}_{i}-\sum_{l=1}^{J} \bar{F}_{i l} \hat{\phi}_{l} .
$$

Equation (5) uses the beta estimates and firm fixed effect estimates from equation (4) and multiplies them by partner $i^{\prime} s$ average characteristics. It is interesting to note that the last term ensures that the partner fixed effects are reduced by the firm fixed effect estimates of all the VC firms where the partner worked multiplied by the fraction of his time he spent at each VC firm.

Some properties of the AKM estimator are noteworthy. An important source of variation is the mobility of partners, which if limited can bias the estimates of the fixed effects. While this issue exists in all studies that use mobility, the concerns are not severe in our sample with $30 \%$ movers. Next, one important benefit of the inclusion of both movers and stayers in the connectedness sample is the increased precision from a larger sample. Including only movers as in Bertrand and Schoar (2003) would shrink the number of partners nearly $70 \%$. The fixed effect estimates themselves have properties similar to other estimators. As shown by Wooldridge (2010) the estimates of the time-varying variable coefficients are unbiased and consistent, while the fixed effects estimates are only unbiased. Last, the connectedness sample requires dropping one partner by normalizing the group mean to zero for each of the connected groups. Further, comparison of fixed effects across these groups requires a normalization as discussed in Abowd, Creecy and Kramarz (2002). None of the results discussed below change when we focus on the one main connected group or simply avoid using the latter normalization procedure. 


\section{A. Fixed effects results}

Estimation of equation (1) starts with the data on the board seat and its investment outcome for VC partners with least four investments. This restriction ensures an ample set of outcomes to estimate both a partner and firm fixed effect. Next, the connectedness grouping eliminates all partners and firms that lack a mover (to or from) during the sample period. In the end, the sample in the AKM estimates for exit valuation has 2,114 partners, 623 VC firms and 603 movers. This collection of VC firms comprises $70 \%$ of all financing events, $74 \%$ of all entrepreneurial firms, $84 \%$ of all dollars invested.

Estimation of the full fixed effects model includes time-varying controls for VC firm experience, entrepreneurial firm stage, dollars invested and VC partner experience. Additionally, the model has year fixed effects, but initially excludes industry fixed effects because most partners and firms rarely switch industries. ${ }^{18}$ Importantly, all regressions include a control for the round number of the investment which addresses concerns about risk differences at different stages. We use the four major outcome variables from above, but our focus will be on the estimates from the log exit valuation regressions. ${ }^{19}$ The $60 \%$ correlation between valuation and the IPO dummy show the variable contains much of the information in the standard outcome measure.

Table $\mathrm{V}$ presents the results of estimating equation (1) using the AKM method. We focus on the estimates' relative contribution to the model $R^{2}$ and on the $\mathrm{p}$-values from a test that

\footnotetext{
${ }^{18}$ The industry fixed effect can only be identified from partners who invest in different industries over time (much like the firm fixed effect). Table VI includes industry fixed effects and finds similar results. Sections IV and V.A discuss possible biases due to industry effects.

${ }^{19}$ For the outcome variables "IPO," "Acquisition" and "Failure" we use the linear probability model. The major cost of the linear probability model are bounded fixed effects estimates. Let $X_{i} \hat{\beta}$ be the predicted values from a general model with this form. Here, the estimates of the one-way fixed effects are bounded $-X_{i} \beta \leq \alpha_{i} \leq 1-x_{i} \beta$. Non-linear models that do not suffer from the incidental parameters problem, such as the conditional logit, do not invite the rich analysis of separating the person and firm fixed effects. This restriction forces us to focus the discussion of the AKM results to the continuous variable outcome "Exit valuation," while still reporting those of the linear probability specification for illustration.
} 
the set of fixed effects are jointly zero (or the same). ${ }^{20}$ The $\frac{\operatorname{cov}(Y, \operatorname{partnerFE})}{\operatorname{var}(Y)}$ in Table V reports the covariance of the dependent variable with the partner and firm fixed effects, each scaled by the dependent variable variance. Rather than focus on the level of $R^{2}$, these measures present the fraction of the total $R^{2}$ attributable to each type of fixed effect. The partner fixed effects explain 2 - 5 times more of the cross-sectional variation in the outcomes than the VC firm fixed effects. For exit valuation, some $46 \%$ of the total $R^{2}$ is attributable to the estimated partner fixed effects (the omitted category are the other control variables) while $8 \%$ of the total $R^{2}$ is attributable to the firm fixed effects. ${ }^{21}$ Thus, the partner explains almost 5 times more than the firm. These stark differences in explanatory power manifest themselves in the hypothesis tests on the fixed effects. The F-test that all the partner fixed effects are the same is rejected in all but the successful acquisitions specifications. The p-value for the analogous test on VC firm fixed effects consistently fails to reject the null. The estimates imply that the average partner has explanatory power in the outcome regressions.

Not only do the estimated fixed effects point to the relative importance of firm and partner, but they also provide a picture on the heterogeneity of partners. The plot of the demeaned partner fixed effects from the largest "connected" group in Figure 1 provides economic magnitudes to the estimates. ${ }^{22}$ The reported fixed effects are in units of log exit valuation and demeaned. The largest connected group - $86 \%$ of the full AKM sample - exhibits significant variation in the fixed effect estimates. When translated into exit value levels, the implied exit value advantage of the top quartile versus bottom quartile partner fixed effect is at least $\$ 78 \mathrm{~m}$. To put this in perspective, $55 \%$ of exits result in no return and the mean exit

\footnotetext{
${ }^{20}$ The reported F-test results only consider the largest connected group.

${ }^{21}$ We also repeated the analysis using the more memory-intensive method of including dummy variables for partner, firm and year. The results, as expected, are the same.

${ }^{22}$ Any report of the estimated fixed effects from AKM must condition on such a grouping because the estimates are relative to a within-group reference fixed effect.
} 
value is $\$ 151$.

\section{Sub-samples}

Reestimation of the full fixed effects model allows us to both better understand the firm versus person and address some possible empirical concerns. Table VI presents five separate regressions for log exit valuation. Column 1 considers the set of VC firms that are in the top $10 \%$ of experience measured by total board seats. The movers and stayers of these firms are then included if they satisfy the connectedness criterion. Focusing on this sample helps us examine whether there are some VC firms that have built up organizational capital over time. The results in column 1 on the F-test are much more favorable towards the firm. This suggests that in the sample of top VC firms, the partner and VC firm are both important in explaining the cross-section of outcomes with the partner explaining over three times as much.

Column 2 considers the first six investments of all VC partners from the full sample. Here, we aim to examine whether the firm is more important for partners with less experience. For example, in an academic setting, younger faculty members may be more impacted by their university. There is some support for this idea in that the partner now explains roughly three times more exit value variation than the firm.

The main model (1) excluded industry fixed effects as they are only identified off of partners that invest in multiple industries. We include them in column 3 of Table VI and find very similar results. However, a large fraction of partners invest in only one industry (primarily biotech). Therefore, in Column 4 we consider only partners who make biotech investments. We again find very similar results. These tests suggest that the relative firm and partner effects are stemming from within industry variation. We also reestimate column 3 including 
industry fixed effects with firms categorized into 17 or alternatively 115 different industries (results reported in the online appendix). The partner continues to explain more than three times more than the firm. We also directly compare partners versus industries dropping firm fixed effects and directly employing the AKM methodology on partners and industries. Now partners who invest only in one industry are 'stayers' and partners who invest across industries are the 'movers' that provide the needed variation. The variance decomposition reported in the online appendix finds the partner explains 6 times more than the industry when using either the 4,17 or 115 industry categorizations. Thus, the partner persistence does not seem to arise from an industry effect.

The last column of Table VI attempts to address concerns about the relative sample size of partners to firms. The main specification has approximately 2,100 partners to 623 firms, possibly giving less power to identify firm fixed effects. We use a random sampling procedure to generate 1,000 different samples where the total number of partners equals the total number of firms. Fixing the set of movers to 300, we construct the connectedness sample and then select stayers to equate the total number of firms and partners. The estimation is run on each sample and the table reports median F-test p-values and the means of the $R^{2}$ contributions. The $R^{2}$ contribution is still in favor of the partner two-to-one, while the F-test continues to fail to reject the null that all firm fixed effects are the same or zero.

\section{Robustness}

The results above are robust to a wide array of specifications. There is a large set of investments that lack an outcome. We treat these firms as either non-IPOs, zero exit values or failed acquisitions depending on the specification of the regression. This treatment is reasonable because we only considered entrepreneurial firms founded prior to 2006 so many of 
the better firms will have exited. Nonetheless, it is possible this assumption is driving some of the results. So we repeat each estimation without investments that lack an exit event as of the end of the sample. The results - persistence, F-tests and $R^{2}$ contributions - are similar for exit value, successful acquisitions and IPO/acquisitions. The results for IPOs are weaker for the partner fixed effects in the AKM model, which is likely driven by the near absence of IPOs post-2001. We conclude that the major results are not driven by our assumptions on outcomes for non-exited investments.

One potential concern of the AKM method is the use of movers. Their movement provides the variation to estimate the VC firm fixed effects and in turn, those of non-movers. Movers' decisions are potentially endogenous to their own performance or that of their past firm. First we examine the similarities between movers and stayers and their firms, and run some robustness checks. Then, in the next subsection, we consider the potential effects on the interpretation of our results.

Table VII details features of the firms and partners that are the source of movers and their destinations. Panel A shows that, not surprisingly, firms that movers leave are larger and older. These firms also invest in earlier stage companies and similar industries.

Panel A of Table VII highlights other features of firms that movers move from and to: for example, performance is higher at firms people leave and lower at firms they go to. This difference suggests that the average mover is being fired from good firms or selecting relatively worse firms to join. However, in unreported results, we find that exclusion of the year fixed effects in the AKM specification dramatically increases the size and importance of VC fixed effects. This difference implies that much of the partner movement is correlated with changes in investment performance over time, i.e., partners seem to leave around (before and after) a peak in VC performance. Thus, the perceived difference is due to market timing 
and the inclusion of year fixed effects is important.

Next, Panel B of Table VII compares the characteristics of movers and stayers, reporting the means and resulting two-sample t-tests for a set of observables. Movers and stayers are similar across most dimensions, excluding investment stage (round number) and total number of investments. Similarly, the analysis of title changes discussed in Section 1 (and in the online appendix) shows that the majority of movers take positions at their second firm with a relatively higher or the same title.

Finally, Panel C of Table VII presents a similar comparison at the firm-level. The AKM firm sample comprises 55\% (623) of VC firms with at least two partners who sat on at least 4 board seats. The excluded firms are those that never had a mover move to or from the firm. Such firms are likely very young or those that failed after their first fund. The exit value and IPO rate differences show that the included firms are larger and generally more successful.

The AKM method is also robust to the time-varying performance measures used in Tables II and III, which Graham, Li and Qiu (2012) note help control for any assortative matching between firms and movers. A better match may result in improved firm performance which could bias the firm fixed effect estimates. Inclusion of both the lagged partner performance and firm performance from Table III has no measurable impact on the conclusion that the partner fixed effects are non-zero and explain a large fraction of the $R^{2}$. The inclusion of these variables does reduce the p-value on the F-test that the firm fixed effects are all zero.

The AKM results control for year fixed effects, however, one might argue that much of the large exit values generated in the asset class were driven by those in the late 1990s. If we exclude all financings in 1997-1999, the results in Table V are quantitatively similar. The pvalue on the F-test for VC firm fixed effects is smaller (9\%), however, the partner fixed effects are still jointly significant and explain much of the variation in exit valuation. 
The estimation of Table $\mathrm{V}$ produces fixed effect estimates relative to a benchmark within each group in the "connected" sample. Therefore, we cannot compare estimated FE between these groups without the normalization procedure of Cornelissen (2008). We address this concern by re-estimating the full model with the largest "connected group" (86\% of the full sample). The result in Table $V$ and is basically unchanged.

\section{A. Endogenous mobility}

Panel B of Table VII shows that movers and stayers are similar across many dimensions, while Panel C of Table VII demonstrates firms in the AKM sample are larger, more active VC firms. If firms and partners in the AKM sample are also unobservably different, it could limit our inference. We now discuss the impact of selection or omitted variables for VC firm and partner fixed effect estimates.

Recall that identification of the VC firm fixed effects comes from changes in mover performance around the move as shown in equation (4). Suppose first that movers are simply partners fired by their past firms. If such partners move to worse firms post-firing and this affects their performance, then the estimation will find a large firm fixed effect. Now suppose that movers are on average high quality partners seeking better prospects at relatively better firms. Again, if these partners move to better firms and it affects their performance, the estimation will attribute this to a larger average firm fixed effect. These two scenarios seem the most economically plausible and show that non-random movement does not necessarily lead to any bias in the estimated firm fixed effects.

However, it is likely that movers who choose to move (those not asked to leave) do so in anticipation of improvements to performance. If partners most likely to be helped by a move are those that make a costly move, then the firm fixed effect may be overestimated 
relative to the true effect on the average partner. Alternatively, movers are a set of partners that are relatively unaffected by their location. Here, the estimate of firm effects are biased downwards. We cannot rule out either concern so one must be cautious in interpreting our results. However, we can examine different subsamples to provide support for the generality of the main result.

In Table VIII columns 1 and 2 we divide partners into two groups - those that moved to a firm with an historically worse IPO rate than their current firm and those that moved to a firm with a relatively better historical IPO rate (where the historical rate is calculated as of the date of the move). These two groups are moving for very different reasons. Those that move to a worse firm are presumably those that are, on average, asked to leave, while those that move to a better firm should be those choosing to seek a better opportunity. In Table VIII column 1 we see that the partner is about 6 times as important as the firm in the group that moved to a worse firm. In Table VIII column 2 we see that the partner is only 2.5 times as important as the firm. If the group of partners that moved to higher performing firms chose to do so, then it is likely that they anticipated positive benefits to their own performance. This sample, therefore, may have too large an estimate of the true firm effect on the average partner. Alternatively, the firm effect is simply larger among higher quality firms. The relatively lower explanatory power of the partner in this sample suggests endogeneity is effecting our results but is not substantially biasing our overall conclusions.

Perhaps firms in the connected sample are connected because partners only move between very similar firms. First note that $86 \%$ of the sample is in our largest connected group, this would mean that the majority of firms have a relatively similar impact on the partner which is what our findings suggest. Second, the average absolute difference in performance in all moves between existing firms is $18.5 \%$ (standard deviation of $14 \%$ ). This means that 
partners on average are moving to firms with very different IPO rates given that the average IPO rate is $12.8 \%$. To address concerns about the characteristics of firms involved in moves, Table VIII columns 3 and 4 divides partners into two groups. Column 4 uses only movers that moved to firms with very similar historical IPO rates (below median absolute difference), while Column 3 considers those that moved to a firm with a historical IPO rate very different to their own firm's historical rate (better or worse). We find very similar results among partners that move to different firms but the estimate of the firm effect is even smaller among partners that move to more similar firms (as would be expected). Thus, some of the finding that the firm is relatively unimportant comes from partners moving between similar firms. ${ }^{23}$

Movers can also exit their firms because of the characteristics of their partners. The specification in equation (1) ignores any externalities between VC partners. For example, all partners may benefit from working with top partners (i.e. both improve) and movers will want to exploit this by working with them. Any positive externalities would increase the partner's performance post-move, which the estimator would attribute to the VC firm fixed effect because performance would differ between positions at VC firms. In the online appendix, we analyze the similarity of the fixed effects among partners at the same firm and do find significant matching in partner quality. However, as Table V makes clear, most specifications find a limited VC firm fixed effect. Thus, while the AKM methodology cannot separate partner externalities from the pure firm effects, our findings suggest that on average both externalities and other firm characteristics are less important than individual partner characteristics.

\footnotetext{
${ }^{23}$ Even though the partners are moving to firms that are observably very different it is possible that partners move to firms that are in actuality unobservably quite similar. In which case the limited effect of the firm could stem from this similarity.
} 
Similar arguments also demonstrate that mean-reversion in VC partner performance may bias the estimated VC firm fixed effect to be non-zero. If partners who are lucky and leave to go to a better firm, they will subsequently mean-revert. This change in performance across the move will be attributed to a firm fixed effect. Alternatively, if partners who are unlucky get fired and go to a new firm, they will also mean-revert. This change would again be attributed to the firm. Both effects would lead to an over estimate the importance of the VC firm, however we find a statistically small average VC firm fixed effects. Mean reversion, however, could combine with other effects to dampen the estimated firm effect. If, for example, partners get lucky and move to a better firm and they are helped by the new firm but simultaneously mean revert then the mean reversions will bias down the effect of the firm.

Our findings suggest that on average firms have relatively limited impact on partner performance, but this is a relative statement. That is, all firms could be quite important but have a similar impact and the fixed effect estimation would find a small relative importance and an insignificant joint p-value. This conclusion would only relate to connected firms as firms in different connect samples cannot be compared. However, the largest connected sample in the AKM specification is $86 \%$ of the sample. Thus, economically what we have found is that on average VC firms seem to be relatively similar to each other.

In general, many endogeneity issues should artificially attribute too large an effect to the VC firm. Since our main finding is that the average firm has relatively little impact on performance, these endogeneity concerns tend to reinforce this finding. Alternatively, the endogeneity in movement has biased our results to produce to low a firm effect. Although we find a similar effect in many subsamples, if the $30 \%$ of partners who move are those whose performance is unaffected by their location then we have underestimated the effect of a move on those partners who stay. 


\section{Conclusion}

The venture capital partner can explain a large fraction of the cross-sectional variation in investment outcomes. The partner's performance is persistent over time, even after controlling for a large set of individual and VC firm controls. Venture capital partners, it seems, also have a style of exit. Overall our work provides strong support for the idea the venture partners have investing skill as well as new insights into the allocation of performance to the firm or partner.

The new fact that VC firm attributes are relatively less important than partner attributes provides insight into another unexplained aspect of venture capital. The optimal venture capital firm size seems to be a few hundred million in assets under management. Few venture capital firms are larger and many top firms cap the amount of money they will accept below total demand. Typical explanations suggest that partner time is the limiting resource but this does not explain why firms don't simply increase the number of partners. Why are there not a few huge venture capital firms with hundreds of partners instead of many firms with a few partners? Other human capital intensive organizations such as investment banks or law firms become quite large. Furthermore, why don't we see mergers or acquisitions between venture capital firms? Zingales and Rajan (1998) argue that without a critical firm asset there is nothing to hold a firm together or make it larger than just what is needed to overcome Coasian frictions. Our findings are consistent with the idea that the organizational capital inside a venture capital firm is limited, in turn limiting firm size. Given this, it appears that brand, process, deal flow, etc. are not critical firm level characteristics, but rather they are partner attributes.

Our work may also benefit limited partners (LPs) who are concerned about investing in 
the new fund of a venture partner or group of venture partners who have left a VC firm to start another VC firm. ${ }^{24}$ Many LPs express reservation because the venture partners may have left the "secret sauce" behind. This decision requires LPs to disentangle individual partner impacts on performance from the possibility that the performance was due to the firm organizational capital the partners left behind. Our results suggest that venture partners will be relatively unaffected by movement and in turn, individual venture partner past performance is a good predictor of future performance.

Overall, the results suggest that venture capital partners are often significantly different from each other, but high quality firms are those with a group of better partners. What then is a VC firm? We suspect that the benefits of joining together may relate to fundraising. This would be an interesting avenue for future research.

${ }^{24}$ See Lerner, Schoar and Wongsunwai (2007) for work on LP decisions and their ability to select funds. 


\section{REFERENCES}

Abowd, John M., Francis Kramarz, and David N. Margolis. 1999. "High Wage Workers and High Wage Firms." Econometrica, 67: 251-333.

Abowd, John M., Robert H. Creecy, and Francis Kramarz. 2002. "Computing Person and Firm Effects Using Linked Longitudinal Employer-Employee Data.” U.S. Census Bureau 2002-06.

Acharya, Viral V., Gottschalg Oliver Hahn Moritz, and Conor Kehoe. Forthcoming. “Corporate Governance and Value Creation: Evidence from Private Equity.” Review of Financial Studies.

Becker, Gary S. 1981. Treatise on the Family. Cambridge:Harvard University Press.

Bertrand, and Schoar. 2003. "Managing With Style: The Effect Of Managers On Firm Policies.” The Quarterly Journal of Economics, 118(4): 1169-1208.

Bottazzi, Laura, Marco Da Rin, and Thomas Hellmann. 2008. "Who are the active investors?: Evidence from venture capital.” Journal of Financial Economics, 89(3): 488-512.

Burdett, Kenneth, and Melvyn G. Coles. 1997. “Marriage and Class.” Quarterly Journal of Economics, 112: 141-168.

Coase, Ronald H. 1988. “The Nature of the Firm: Origin, Meaning, Influence.” Journal of Law, Economics, and Organization, 4.

Cornelissen, Thomas. 2008. "The Stata command felsdvreg to fit a linear model with two high-dimensional fixed effects.” Stata Journal, 8(2): 170-189. 
Ertugrul, Mine, and Karthik Krishnan. 2011. "Advisor Skill and Acquisition Performance: Do Investment Bankers Make a Difference?"

Gompers, Paul, Anna Kovner, and Josh Lerner. 2009. "Specialization and Success: Evidence from Venture Capital." Journal of Economics \& Management Strategy, 18(3): 817-844.

Gompers, Paul, Anna Kovner, Josh Lerner, and David Scharfstein. 2010. “Performance persistence in entrepreneurship." Journal of Financial Economics, 96(1): 18-32.

Graham, John R., Si Li, and Jiaping Qiu. 2012. “Managerial Attributes and Executive Compensation." Review of Financial Studies, 25(1): 144-186.

Harris, Robert S., Tim Jenkinson, Steven N. Kaplan, and Ruediger Stucke. 2013. "Has Persistence Persisted in Private Equity? Evidence From Buyout and Venture Capital Funds."

Hart, Oliver. 1989. "An Economist's Perspective on the Theory of the Firm." Columbia Law Review, 89(7): 1757-1774.

Hellmann, Thomas, and Manju Puri. 2002. "Venture Capital and the Professionalization of Start-Up Firms: Empirical Evidence." Journal of Finance, 57(1): 169-197.

Hochberg, Yael, Alexander Ljungqvist, and Yang Lu. 2007. "Whom You Know Matters: Venture Capital Networks and Investment Performance.” Journal of Finance, 62(1).

Hochberg, Yael V., Alexander Ljungqvist, and Annette Vissing-Jorgensen. 2012. "Informational Hold-up and Performance Persistence in Venture Capital.”

Kaplan, Steven N., and Antoinette Schoar. 2005. "Private Equity Performance: Returns, Persistence, and Capital Flows." Journal of Finance, 60(4). 
Klein, Benjamin. 1988. "Vertical Integration as Organizational Ownership: The Fisher Body-General Motors Relationship Revisited." Journal of Law, Economics and Organization, 4(1): 199-213.

Kremer, Michael. 1993. “The O-ring theory of economic development.” Quarterly Journal of Economics, 103: 551-575.

Lerner, Josh, Antoinette Schoar, and Wan Wongsunwai. 2007. "Smart Institutions, Foolish Choices: The Limited Partner Performance Puzzle.” Journal of Finance, 62(2): 731-764.

Phalippou, Ludovic. 2010. "Venture capital funds: Flow-performance relationship and performance persistence." Journal of Banking \& Finance, 34(3): 568-577.

Sahlman, William. 2010. "Risk and Reward in Venture Capital." Harvard Business School Note 811-036, 1-37.

Shimer, Robert, and Lones Smith. 2000. “Assortative matching and search.” Econometrica, 68: 343-369.

Smith, Richard, Roberto Pedace, and Vijay Sathe. 2010. "Venture Capital Fund Performance: The Effects of Exits, Abandonment, Persistence, Experiance, and Reputation.” working paper.

Sorensen, Morton. 2007. "How smart is smart money? An empirical two-sided matching model of venture capital." Journal of Finance, 62: 2725-62.

Williamson, Oliver E., and Sidney G. Winter, ed. 1993. The Nature of the Frim, Origins, Evolutions, and Development. London:Oxford University Press.

Wooldridge, Jeffery M. 2010. Econometric Analysis of Cross Section and Panel Data. MIT. 
Zarutskie, Rebecca. 2010. "The role of top management team human capital in venture capital markets: Evidence from first-time funds.” Journal of Business Venturing, 25(1): 155172.

Zingales, Luigi, and Ragu Rajan. 1998. "Power in a Theory of the Firm.” Quarterly Journal of Economics, 113: 387-432. 


\section{Tables and Figures}

\section{Figure 1. Fixed Effect Distribution: Exit Value}

Notes: Figure displays the distribution estimated fixed effects from the AKM regression using $\log$ valuation for IPO or successful acquisition as the dependent variable ( 0 if no exit, failure or unreported). The estimates are normalized so the mean value of the partner fixed effects is zero. The sample of estimated fixed effects only includes those in the largest "connected" sample (i.e. sets of firms connected by movers) that comprise $86 \%$ of VC partners in the full specification. This restriction ensures that the fixed effects estimates are comparable.

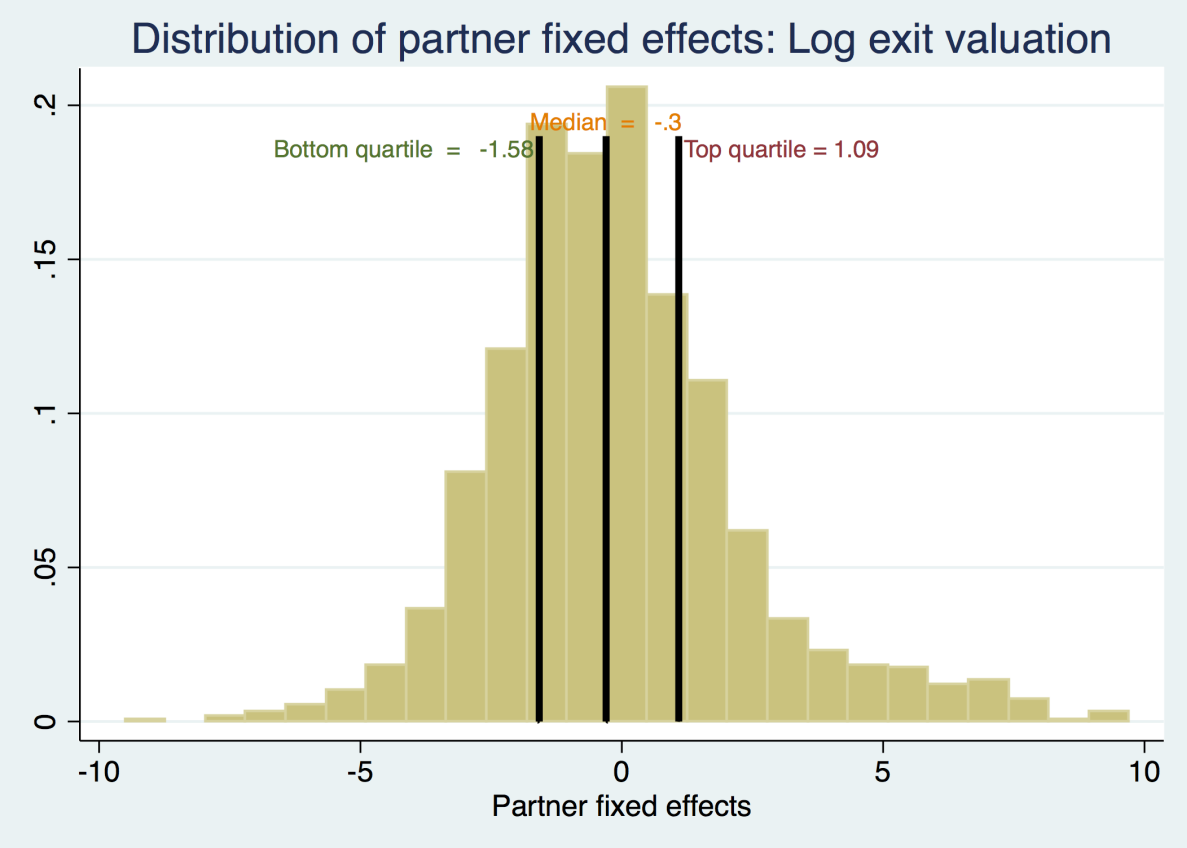


Notes: Table reports the characteristics of the sample of partners in most analyses below. The unit of observation is the VC partner matched to an entrepreneurial investment through a board seat. Column "Two" summarizes the partners at their second investment, "Three" at their third investment and so on. "Other" pools all the excluded investment numbers and "Total" is the full sample. "IPO" is a dummy for an IPO exit, "\% IPO $t-1$ " is the fraction of IPOs in the partner's history as of that investment and "Successful Acq." is a dummy for an acquisition exit that has a reported exit value greater than two times capital invested ("Fail" is for failures). "Log exit value" is the log of one plus the exit value (in millions) for a given investment, "\% VC IPO (-i)" is the fraction of IPOs for all partners not including the one of interest at the VC firm. "Years experience" is the number of years experience as of the board seat, "\# VC firm investments" is the total number of board seat investments made by the partners VC firm. "Round \#" is the round number of the board seat investment and "Dollars invested (log)" is the investment amount. "Years since previous board" tracks the number of years between the current and last board seat, while "CA" and "MA" identify the state of the entrepreneurial firm. "IT" is the fraction of investments in information technology and "Biotech" is the fraction of biotech investments.

\begin{tabular}{|c|c|c|c|c|c|c|}
\hline & \multicolumn{6}{|c|}{ Investment Experience } \\
\hline & Two & Three & Five & Seven & Other & Total \\
\hline IPO & $\begin{array}{c}0.129 \\
(0.335)\end{array}$ & $\begin{array}{c}0.126 \\
(0.332)\end{array}$ & $\begin{array}{c}0.139 \\
(0.346)\end{array}$ & $\begin{array}{c}0.126 \\
(0.332)\end{array}$ & $\begin{array}{c}0.126 \\
(0.332)\end{array}$ & $\begin{array}{c}0.128 \\
(0.334)\end{array}$ \\
\hline$\%$ IPO t-1 & $\begin{array}{c}0.166 \\
(0.372)\end{array}$ & $\begin{array}{c}0.178 \\
(0.294)\end{array}$ & $\begin{array}{c}0.184 \\
(0.238)\end{array}$ & $\begin{array}{c}0.199 \\
(0.217)\end{array}$ & $\begin{array}{c}0.221 \\
(0.210)\end{array}$ & $\begin{array}{c}0.202 \\
(0.259)\end{array}$ \\
\hline Successful Acq. & $\begin{array}{c}0.100 \\
(0.300)\end{array}$ & $\begin{array}{l}0.0942 \\
(0.292)\end{array}$ & $\begin{array}{c}0.103 \\
(0.304)\end{array}$ & $\begin{array}{c}0.104 \\
(0.305)\end{array}$ & $\begin{array}{l}0.0987 \\
(0.298)\end{array}$ & $\begin{array}{l}0.0991 \\
(0.299)\end{array}$ \\
\hline$\%$ fail $t-1$ & $\begin{array}{c}0.379 \\
(0.484)\end{array}$ & $\begin{array}{c}0.368 \\
(0.359)\end{array}$ & $\begin{array}{c}0.353 \\
(0.270)\end{array}$ & $\begin{array}{c}0.346 \\
(0.227)\end{array}$ & $\begin{array}{c}0.327 \\
(0.217)\end{array}$ & $\begin{array}{c}0.345 \\
(0.303)\end{array}$ \\
\hline Log exit value & $\begin{array}{l}1.613 \\
(2.282)\end{array}$ & $\begin{array}{c}1.594 \\
(2.261)\end{array}$ & $\begin{array}{l}1.720 \\
(2.344)\end{array}$ & $\begin{array}{l}1.701 \\
(2.363)\end{array}$ & $\begin{array}{l}1.719 \\
(2.412)\end{array}$ & $\begin{array}{c}1.684 \\
(2.363)\end{array}$ \\
\hline \% VC IPO (-i) & $\begin{array}{c}0.212 \\
(0.236)\end{array}$ & $\begin{array}{c}0.216 \\
(0.227)\end{array}$ & $\begin{array}{c}0.228 \\
(0.211)\end{array}$ & $\begin{array}{c}0.226 \\
(0.190)\end{array}$ & $\begin{array}{c}0.226 \\
(0.177)\end{array}$ & $\begin{array}{c}0.223 \\
(0.199)\end{array}$ \\
\hline Years experience & $\begin{array}{c}1.689 \\
(1.910)\end{array}$ & $\begin{array}{c}2.811 \\
(2.481)\end{array}$ & $\begin{array}{c}4.345 \\
(2.911)\end{array}$ & $\begin{array}{c}5.650 \\
(3.261)\end{array}$ & $\begin{array}{c}7.483 \\
(4.722)\end{array}$ & $\begin{array}{c}5.506 \\
(4.555)\end{array}$ \\
\hline \# VC firm investments & $\begin{array}{c}76.37 \\
(124.5)\end{array}$ & $\begin{array}{c}85.22 \\
(126.7)\end{array}$ & $\begin{array}{c}106.7 \\
(146.5)\end{array}$ & $\begin{array}{c}125.5 \\
(147.6)\end{array}$ & $\begin{array}{c}174.8 \\
(188.7)\end{array}$ & $\begin{array}{c}137.4 \\
(171.4)\end{array}$ \\
\hline Round \# & $\begin{array}{c}2.004 \\
(1.391)\end{array}$ & $\begin{array}{c}2.051 \\
(1.451)\end{array}$ & $\begin{array}{c}2.075 \\
(1.502)\end{array}$ & $\begin{array}{c}1.997 \\
(1.433)\end{array}$ & $\begin{array}{c}1.991 \\
(1.412)\end{array}$ & $\begin{array}{c}2.009 \\
(1.423)\end{array}$ \\
\hline Dollars invested & $\begin{array}{l}12.43 \\
(23.39)\end{array}$ & $\begin{array}{l}12.05 \\
(20.52)\end{array}$ & $\begin{array}{c}11.75 \\
(18.63)\end{array}$ & $\begin{array}{c}11.09 \\
(15.71)\end{array}$ & $\begin{array}{l}12.53 \\
(20.84)\end{array}$ & $\begin{array}{l}12.29 \\
(20.78)\end{array}$ \\
\hline $\begin{array}{l}\text { Years since } \\
\text { previous board }\end{array}$ & $\begin{array}{c}1.671 \\
(1.890)\end{array}$ & $\begin{array}{c}1.178 \\
(1.357)\end{array}$ & $\begin{array}{c}0.905 \\
(1.038)\end{array}$ & $\begin{array}{c}0.757 \\
(0.852)\end{array}$ & $\begin{array}{c}0.740 \\
(0.877)\end{array}$ & $\begin{array}{c}0.968 \\
(1.233)\end{array}$ \\
\hline CA & $\begin{array}{c}0.367 \\
(0.482)\end{array}$ & $\begin{array}{c}0.401 \\
(0.490)\end{array}$ & $\begin{array}{c}0.418 \\
(0.493)\end{array}$ & $\begin{array}{c}0.446 \\
(0.497)\end{array}$ & $\begin{array}{c}0.486 \\
(0.500)\end{array}$ & $\begin{array}{c}0.446 \\
(0.497)\end{array}$ \\
\hline MA & $\begin{array}{c}0.125 \\
(0.331)\end{array}$ & $\begin{array}{c}0.118 \\
(0.322)\end{array}$ & $\begin{array}{c}0.119 \\
(0.324)\end{array}$ & $\begin{array}{c}0.129 \\
(0.335)\end{array}$ & $\begin{array}{c}0.128 \\
(0.334)\end{array}$ & $\begin{array}{c}0.125 \\
(0.331)\end{array}$ \\
\hline IT & $\begin{array}{c}0.534 \\
(0.499)\end{array}$ & $\begin{array}{c}0.547 \\
(0.498)\end{array}$ & $\begin{array}{c}0.545 \\
(0.498)\end{array}$ & $\begin{array}{c}0.565 \\
(0.496)\end{array}$ & $\begin{array}{c}0.571 \\
(0.495)\end{array}$ & $\begin{array}{c}0.559 \\
(0.497)\end{array}$ \\
\hline Biotech & $\begin{array}{c}0.245 \\
(0.430)\end{array}$ & $\begin{array}{c}0.247 \\
(0.431)\end{array}$ & $\begin{array}{c}0.250 \\
(0.433)\end{array}$ & $\begin{array}{c}0.249 \\
(0.432)\end{array}$ & $\begin{array}{c}0.240 \\
(0.427)\end{array}$ & $\begin{array}{c}0.243 \\
(0.429)\end{array}$ \\
\hline Observations & 4,860 & 3,636 & 2,083 & 1,536 & 13,551 & 25,666 \\
\hline
\end{tabular}




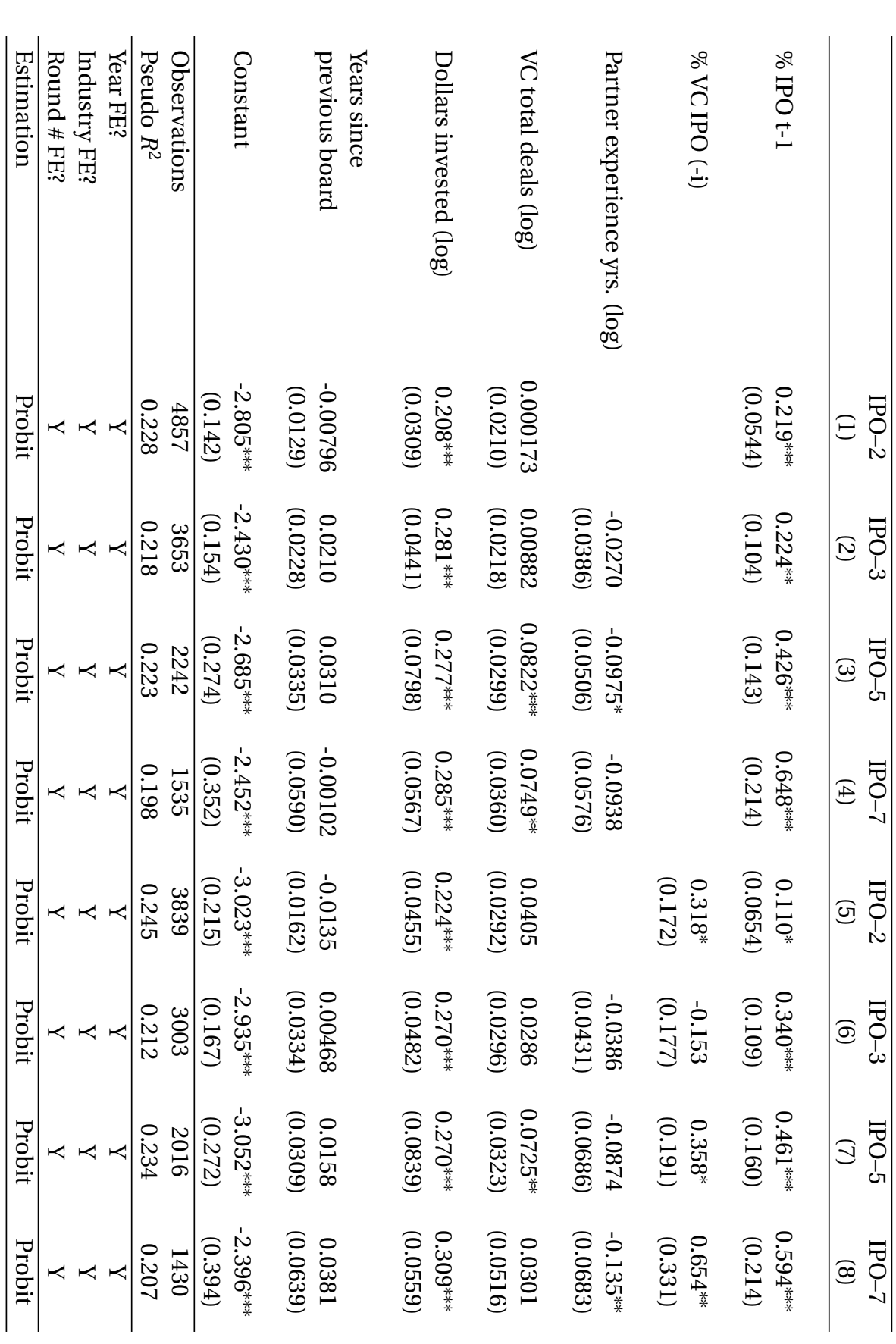

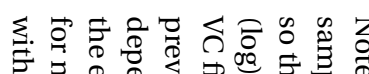

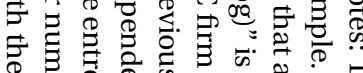
仹要要 क क 0 \%

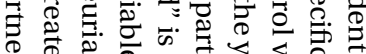

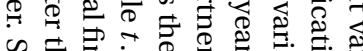

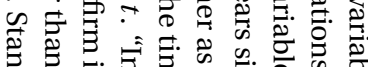
跣.

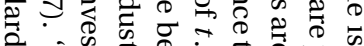

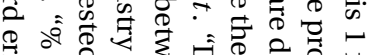

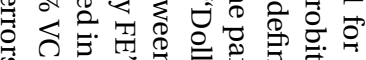

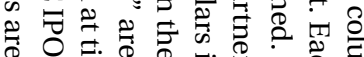

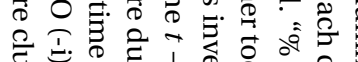

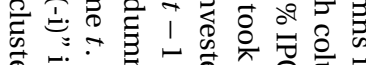

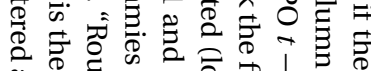

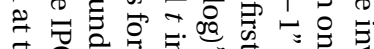

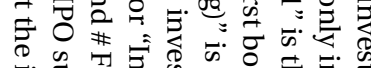

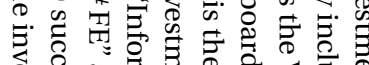
क

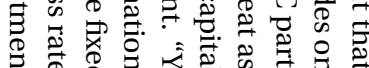
के

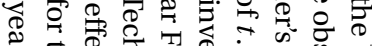

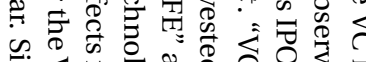

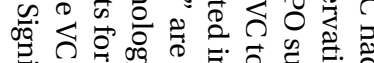

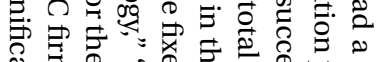
ज्ञ

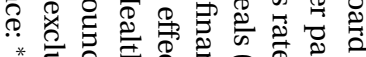

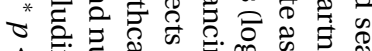

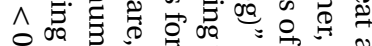

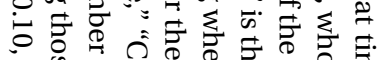
*

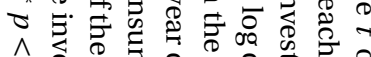

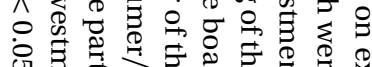

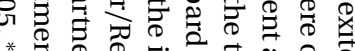

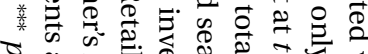

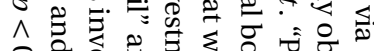

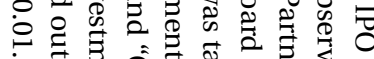
ठิ

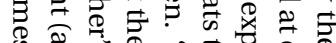
की

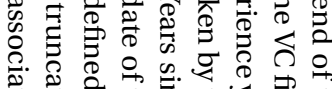

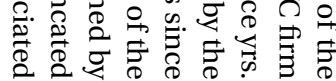


TABLE III-PARTNER PERFormanCE PERSISTENCE By EXIT TYPES

Notes: Probit regressions (OLS for columns 3 and 6) of three different dependent variables with the same specification as Table II. Each column only includes one observation per partner who were observed at only one VC firm. ACQ $t$ is 1 if the partner's $t$ 'th board seat investment resulted in a successful acquisition (i.e. sold for at least twice capital invested) and "Fail" is 1 if it resulted in an failure or the firm had yet to exit by the end of the sample. "Exit value $t$ " is the log of the exit value at sale of the entrepreneurial firm (0 if failure or missing). "\% Acq. $t-1$ " is the fraction of the partner's investments prior to $t$ that has a successful acquisition. "Fail rate $t-1$ " is the same, but the fraction that failed. "Avg. Exit value $t-1$ " is the log of one plus average exit values prior to this investment. "Partner experience yrs. (log)" is the log of the years of partner experience as a board member. See Table II for the remaining control variable definitions. Standard errors are clustered at the investment year. Note that observation counts differ slightly from Table II because of observations dropped due to multicollinearity. Significance: ${ }^{*} p<0.10,{ }^{* *} p<0.05$, ${ }^{* * *}$

\begin{tabular}{|c|c|c|c|c|c|c|}
\hline & $\begin{array}{l}\text { ACQ-3 } \\
\text { (1) }\end{array}$ & $\begin{array}{c}\text { Fail-3 } \\
(2)\end{array}$ & $\begin{array}{c}\text { Exit Value-3 } \\
\text { (3) }\end{array}$ & $\begin{array}{c}\text { ACQ-5 } \\
\text { (4) }\end{array}$ & $\begin{array}{l}\text { Fail-5 } \\
(5)\end{array}$ & $\begin{array}{c}\text { Exit value }-5 \\
\text { (6) }\end{array}$ \\
\hline$\%$ Acq. $\mathrm{t}-1$ & $\begin{array}{l}0.275^{* *} \\
(0.134)\end{array}$ & & & $\begin{array}{l}0.442^{* *} \\
(0.189)\end{array}$ & & \\
\hline \% Fail t-1 & & $\begin{array}{l}0.0709^{*} \\
(0.0412)\end{array}$ & & & $\begin{array}{l}0.297^{* *} \\
(0.126)\end{array}$ & \\
\hline Avg. Exit value t-1 & & & $\begin{array}{c}0.0844^{* * *} \\
(0.0167)\end{array}$ & & & $\begin{array}{l}0.107^{\text {*** }} \\
(0.0348)\end{array}$ \\
\hline Partner experience yrs. (log) & $\begin{array}{l}-0.0181 \\
(0.0365)\end{array}$ & $\begin{array}{c}0.0624^{* * *} \\
(0.0190)\end{array}$ & $\begin{array}{l}-0.0516 \\
(0.0473)\end{array}$ & $\begin{array}{l}-0.0570 \\
(0.0609)\end{array}$ & $\begin{array}{c}0.0547 \\
(0.0401)\end{array}$ & $\begin{array}{l}-0.183 \\
(0.113)\end{array}$ \\
\hline VC total deals (log) & $\begin{array}{c}0.0321 \\
(0.0205)\end{array}$ & $\begin{array}{c}-0.0521^{* * *} \\
(0.0164)\end{array}$ & $\begin{array}{c}0.0236 \\
(0.0221)\end{array}$ & $\begin{array}{c}0.0299 \\
(0.0361)\end{array}$ & $\begin{array}{c}-0.0575^{* * *} \\
(0.0144)\end{array}$ & $\begin{array}{c}0.113^{* *} \\
(0.0420)\end{array}$ \\
\hline Dollars invested (log) & $\begin{array}{c}0.0178 \\
(0.0273)\end{array}$ & $\begin{array}{c}-0.0828^{* * * *} \\
(0.0301)\end{array}$ & $\begin{array}{l}0.375^{* * *} \\
(0.0514)\end{array}$ & $\begin{array}{l}-0.0812^{*} \\
(0.0471)\end{array}$ & $\begin{array}{l}-0.0229 \\
(0.0286)\end{array}$ & $\begin{array}{l}0.254^{* * *} \\
(0.0706)\end{array}$ \\
\hline $\begin{array}{l}\text { Years since } \\
\text { previous board }\end{array}$ & $\begin{array}{c}0.0248 \\
(0.0326)\end{array}$ & $\begin{array}{l}-0.0282^{*} \\
(0.0161)\end{array}$ & $\begin{array}{c}0.0256 \\
(0.0461)\end{array}$ & $\begin{array}{l}-0.0627 \\
(0.0456)\end{array}$ & $\begin{array}{c}0.0404 \\
(0.0356)\end{array}$ & $\begin{array}{l}0.00977 \\
(0.0465)\end{array}$ \\
\hline Constant & $\begin{array}{c}-2.127^{* * *} \\
(0.109)\end{array}$ & $\begin{array}{l}1.119 * * * \\
(0.0833)\end{array}$ & $\begin{array}{c}2.654^{* * *} \\
(0.126)\end{array}$ & $\begin{array}{c}-1.558^{* * *} \\
(0.243)\end{array}$ & $\begin{array}{c}0.675^{\text {**** }} \\
(0.139)\end{array}$ & $\begin{array}{c}2.783^{* * *} \\
(0.206)\end{array}$ \\
\hline $\begin{array}{l}\text { Observations } \\
R^{2}\end{array}$ & 3566 & 3566 & $\begin{array}{l}3566 \\
0.143\end{array}$ & 2239 & 2239 & $\begin{array}{l}2239 \\
0.144\end{array}$ \\
\hline Pseudo $R^{2}$ & 0.048 & 0.062 & & 0.043 & 0.073 & \\
\hline Year FE? & $\mathrm{Y}$ & $\mathrm{Y}$ & $\mathrm{Y}$ & $\mathrm{Y}$ & $\mathrm{Y}$ & $\mathrm{Y}$ \\
\hline Industry FE? & $\mathrm{Y}$ & $\mathrm{Y}$ & $\mathrm{Y}$ & $\mathrm{Y}$ & $\mathrm{Y}$ & $\mathrm{Y}$ \\
\hline Round \# FE? & $\mathrm{Y}$ & $\mathrm{Y}$ & $\mathrm{Y}$ & $\mathrm{Y}$ & $\mathrm{Y}$ & $\mathrm{Y}$ \\
\hline Model & Probit & Probit & OLS & Probit & Probit & OLS \\
\hline
\end{tabular}




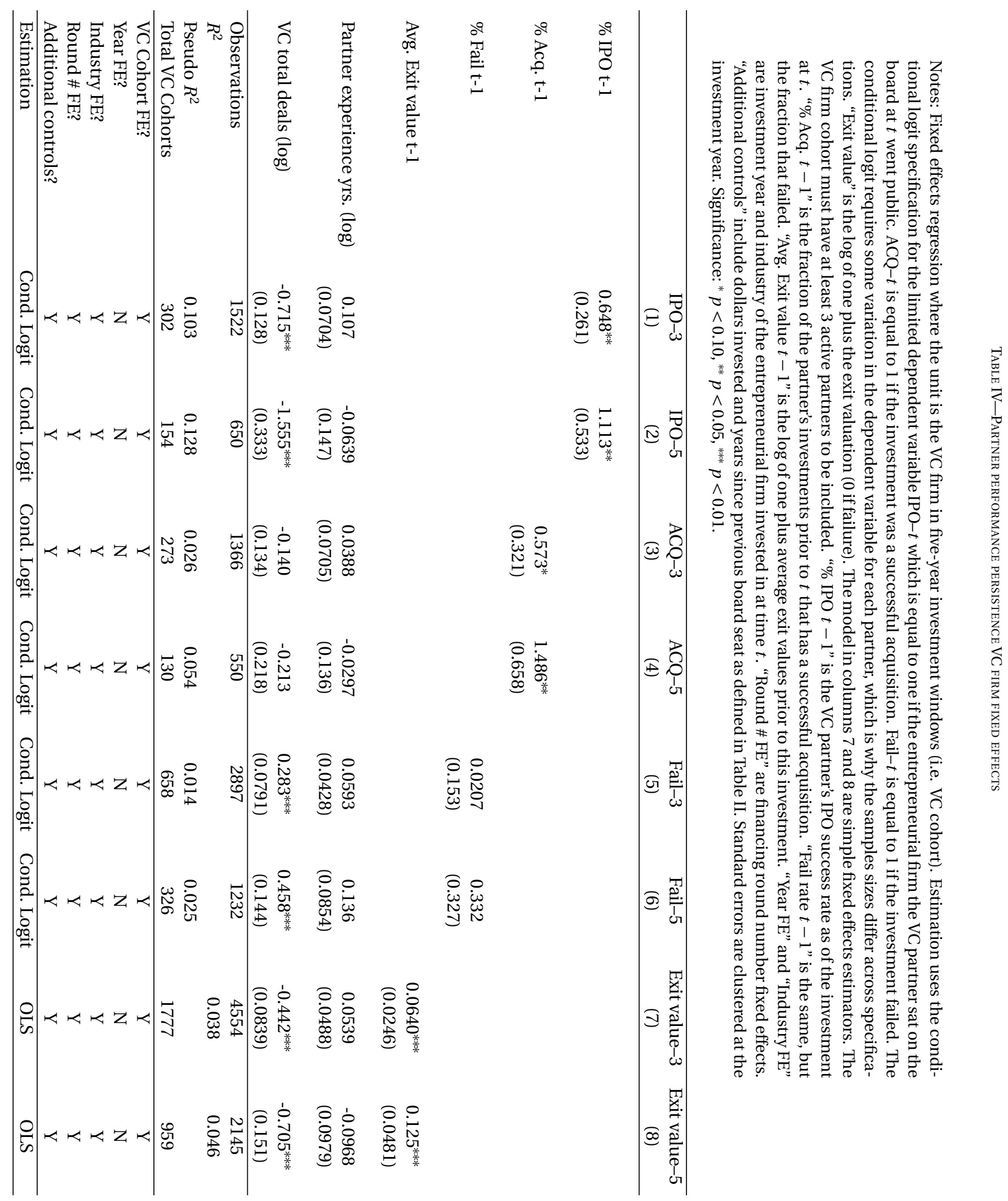


Notes: Three-way fixed effects regressions using the method detailed in Abowd, Creecy and Kramarz (2002) and Abowd, Kramarz and Margolis (1999) to estimate both the VC firm and VC partner fixed effects. Estimation implemented using the Stata code "felsdvreg" as described in Cornelissen (2008). The unit of observation is the VC partner, board seat and entrepreneurial firm outcome. Column 1 uses log of one plus the exit valuation as the dependent variable ( 0 if failed or missing), column 2 uses the dummy variable "IPO" and column 3 uses a successful acquisition ( $\geq 2$ times capital invested) dummy variable. Column 4 uses the dummy variable defined to be 1 if the investment failed. Firms without an IPO or successful acquisition have a 0 as the dependent variable in columns 2 - 3. The rows for "F-test on FE" report the p-value from the null that the estimated VC partner or VC firm fixed effects are jointly zero. $\frac{\operatorname{cov}(Y, \operatorname{PartnerFE})}{\operatorname{var}(Y)}$ reports the "beta" for the partner FE (similarly for the last row and VC FE). The percentages in parentheses report the fraction of the $R^{2}$ that are attributable to the firm and partner FEs (see Graham, Li and Qiu (2012) for details). "Round \# (log)" is the log of the financing sequence number, "Dollars invested (log)" is the log of the total dollars invested in the financing round when the board seat is taken and "VC experience yrs. (log)" is the log of the total board seats made by the VC firm as of the current investment. "Partner experience yrs. (log)" is the log of the total boards seats taken by the VC partner as of the investment. "Fund sequence (log)" is the log of the fund sequence, set to the five-year windows since VC founding. "Year FE" are year fixed effects for the investment year of the board seat. "Industry FE" are dummies for the investment industry. "Mean dep. variable" reports the mean of the dependent variable. "\# VC firms" is the total VC firms in the sample. Robust standard errors clustered at the VC firm are reported in parentheses. Significance: ${ }^{*} p<0.10$, ** $p<0.05,{ }^{* * *} p<0.01$.

\begin{tabular}{|c|c|c|c|c|}
\hline & $\begin{array}{l}\text { Exit Valuation } \\
\text { (1) }\end{array}$ & $\begin{array}{c}\text { IPO } \\
(2)\end{array}$ & $\begin{array}{c}\text { Acquisition } \\
\text { (3) }\end{array}$ & $\begin{array}{c}\text { Failure } \\
(4)\end{array}$ \\
\hline \multicolumn{5}{|c|}{ Relative importance of estimates in $R^{2} . \%$ 's are fraction $R^{2}$ explained by covariate. } \\
\hline \multirow{2}{*}{$\begin{array}{l}\frac{\operatorname{cov}(Y, P a r t n e r F E)}{v a r(Y)} \\
\frac{\operatorname{cov}(Y, V C F E)}{\operatorname{var}(Y)}\end{array}$} & $0.12(46 \%)$ & $0.10(38 \%)$ & $0.10(62 \%)$ & $0.12(57 \%)$ \\
\hline & $0.02(8 \%)$ & $0.04(12 \%)$ & $0.03(25 \%)$ & $0.02(10 \%)$ \\
\hline \multicolumn{5}{|l|}{ F-test on FE (p-value) } \\
\hline VC Partner FE & $<0.01$ & 0.06 & 0.79 & $<0.01$ \\
\hline VC Firm FE & 0.78 & 0.70 & 0.3 & 0.74 \\
\hline \multirow[t]{2}{*}{ Round \# (log) } & $0.352^{* * *}$ & $0.0506^{* * *}$ & -0.00526 & $-0.0760^{* * *}$ \\
\hline & $(0.0473)$ & $(0.00679)$ & $(0.00615)$ & $(0.00861)$ \\
\hline \multirow[t]{2}{*}{ Dollars invested (log) } & $0.281^{* * *}$ & $0.0348^{* * *}$ & -0.00222 & $-0.0380^{* * *}$ \\
\hline & $(0.0296)$ & $(0.00409)$ & $(0.00360)$ & $(0.00604)$ \\
\hline \multirow[t]{2}{*}{ Partner experience yrs. (log) } & -0.115 & -0.00966 & -0.00746 & 0.0132 \\
\hline & $(0.0763)$ & $(0.0103)$ & $(0.00981)$ & $(0.0137)$ \\
\hline \multirow[t]{2}{*}{ VC experience yrs. (log) } & -0.0414 & -0.00678 & $-0.0150^{*}$ & 0.00850 \\
\hline & $(0.0653)$ & $(0.00878)$ & $(0.00782)$ & $(0.0128)$ \\
\hline \multirow[t]{2}{*}{ Fund sequence (log) } & 0.231 & 0.00472 & $0.0387^{*}$ & $-0.0560^{*}$ \\
\hline & $(0.146)$ & $(0.0182)$ & $(0.0210)$ & $(0.0308)$ \\
\hline Observations & 19617 & 19617 & 19617 & 19617 \\
\hline$R^{2}$ & .26 & .27 & .16 & .22 \\
\hline Mean dep. variable & $\$ 151 \mathrm{~m}$ & .14 & .11 & .40 \\
\hline \# Movers & 603 & 603 & 603 & 603 \\
\hline \# Stayers & 1511 & 1511 & 1511 & 1511 \\
\hline \# VC Firms & 625 & 625 & 625 & 625 \\
\hline Year FE? & $\mathrm{Y}$ & $\mathrm{Y}$ & $\mathrm{Y}$ & $\mathrm{Y}$ \\
\hline Industry FE? & $\mathrm{N}$ & $\mathrm{N}$ & $\mathrm{N}$ & $\mathrm{N}$ \\
\hline
\end{tabular}


Notes: Three-way fixed effects regressions using the method detailed in Abowd, Creecy and Kramarz (2002) and Abowd, Kramarz and Margolis (1999) to estimate both the VC firm and VC partner fixed effects. Estimation implemented using the Stata code "felsdvreg" as described in Cornelissen (2008). The unit of observation is the VC partner, board seat and entrepreneurial firm outcome. All regressions use the log of exit valuation as in Table V column 1. "Top VCs" considers only the set of VCs in the top $10 \%$ of total investment experience who are also connected by at least on VC partner mover. " $\leq 6$ inv." includes only movers and stayers for the first 6 of their investments over their whole career (i.e. when the partners are young). "Ind. FE" runs the full AKM specification with industry fixed effects. "Bio." includes only partners that made healthcare investments. "Subset stayers" is the result of a set of random samples of partners and firms such that the total number of partners equals the number of firms. The AKM regression was run 1000 times over the random samples. We report the median p-values and average proportion of $R^{2}$. Coefficient estimates are excluded, but mimic those of column (1) of Table V. Robust standard errors are clustered at the VC firm reported in parentheses. Significance: ${ }^{*} p<0.10,{ }^{* *} p<0.05$, *** $p<0.01$.

\begin{tabular}{|c|c|c|c|c|c|}
\hline & $\begin{array}{c}\text { Top VCs } \\
\text { (1) }\end{array}$ & $\begin{array}{c}\leq 6 \text { inv. } \\
(2)\end{array}$ & $\begin{array}{c}\text { Ind. FE } \\
\text { (3) }\end{array}$ & $\begin{array}{l}\text { Bio. } \\
(4)\end{array}$ & $\begin{array}{c}\text { Subset stayers } \\
\text { (5) }\end{array}$ \\
\hline $\begin{array}{l}\text { Relative importance of estim } \\
\frac{\operatorname{cov}(Y, P a r t n e r F E)}{v a r(Y)} \\
\frac{\operatorname{cov}(Y, V C F E)}{\operatorname{var}(Y)}\end{array}$ & $\begin{array}{l}\text { tes in } R^{2} . \% \text { 's } \\
0.09(40 \%) \\
0.03(13 \%)\end{array}$ & $\begin{array}{r}\text { are fraction } \\
0.23(57 \%) \\
0.04(17 \%)\end{array}$ & $\begin{array}{c}2 \text { explained } \\
0.12(46 \%) \\
0.02(8 \%)\end{array}$ & $\begin{array}{c}\text { y covariate. } \\
0.13(50 \%) \\
0.02(8 \%)\end{array}$ & $\begin{array}{l}0.13(42 \%) \\
0.06(20 \%)\end{array}$ \\
\hline $\begin{array}{l}\text { F-test on FE (p-value) } \\
\text { VC Partner FE } \\
\text { VC Firm FE }\end{array}$ & $\begin{array}{c}<0.01 \\
0.08\end{array}$ & $\begin{array}{c}<0.01 \\
0.49\end{array}$ & $\begin{array}{l}0.01 \\
0.50\end{array}$ & $\begin{array}{c}<0.01 \\
0.51\end{array}$ & $\begin{array}{c}\text { Median } \\
0.04 \\
0.61\end{array}$ \\
\hline Round \# (log) & $\begin{array}{l}0.325^{\text {**** }} \\
(0.0705)\end{array}$ & $\begin{array}{l}0.326^{* * *} \\
(0.0752)\end{array}$ & $\begin{array}{l}0.371^{* * * *} \\
(0.0523)\end{array}$ & $\begin{array}{l}0.316^{* * *} \\
(0.0699)\end{array}$ & \\
\hline Dollars invested (log) & $\begin{array}{l}0.295^{\text {**** }} \\
(0.0430)\end{array}$ & $\begin{array}{l}0.272^{* * *} \\
(0.0442)\end{array}$ & $\begin{array}{l}0.291^{* * *} \\
(0.0341)\end{array}$ & $\begin{array}{l}0.334^{* * *} \\
(0.0395)\end{array}$ & \\
\hline Partner experience yrs. (log) & $\begin{array}{l}-0.157 \\
(0.143)\end{array}$ & $\begin{array}{l}-0.135 \\
(0.107)\end{array}$ & $\begin{array}{c}-0.137 \\
(0.0865)\end{array}$ & $\begin{array}{l}-0.176 \\
(0.122)\end{array}$ & \\
\hline VC experience yrs. (log) & $\begin{array}{c}-0.136 \\
(0.0905)\end{array}$ & $\begin{array}{c}0.0480 \\
(0.0972)\end{array}$ & $\begin{array}{l}-0.0381 \\
(0.0730)\end{array}$ & $\begin{array}{c}-0.138 \\
(0.0988)\end{array}$ & \\
\hline Fund sequence (log) & $\begin{array}{c}0.283 \\
(0.248)\end{array}$ & $\begin{array}{l}0.0480 \\
(0.217)\end{array}$ & $\begin{array}{l}0.315^{\text {** }} \\
(0.152)\end{array}$ & $\begin{array}{c}0.221 \\
(0.219)\end{array}$ & \\
\hline Observations & 9720 & 9381 & 14730 & 7981 & \\
\hline$R^{2}$ & .24 & .37 & .28 & .25 & .31 \\
\hline \# Movers & 90 & 432 & 462 & 278 & 300 \\
\hline \# Stayers & 846 & 1440 & 972 & 509 & 105 \\
\hline \# VC Firms & 81 & 515 & 530 & 373 & 427 \\
\hline Year FE? & $\mathrm{Y}$ & $\mathrm{Y}$ & $\mathrm{Y}$ & $\mathrm{Y}$ & $\mathrm{Y}$ \\
\hline Industry FE? & $\mathrm{N}$ & $\mathrm{N}$ & $\mathrm{Y}$ & $\mathrm{N}$ & $\mathrm{N}$ \\
\hline
\end{tabular}




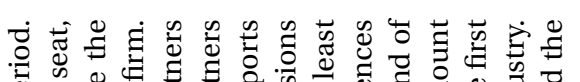

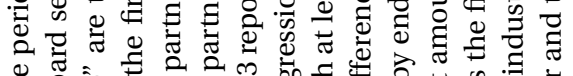
苛造

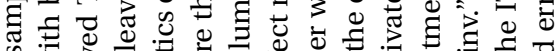

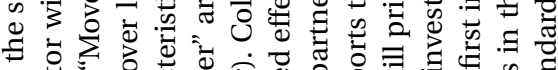

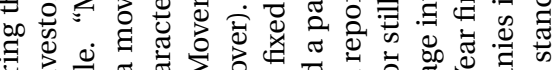

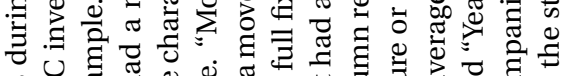

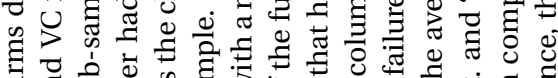

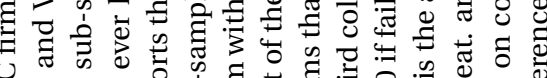

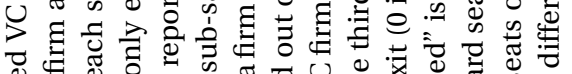

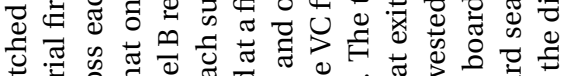

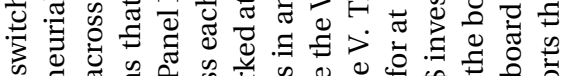

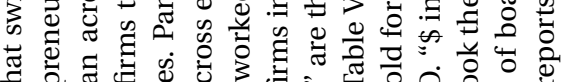

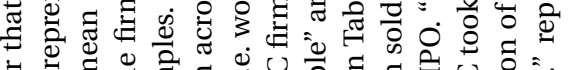

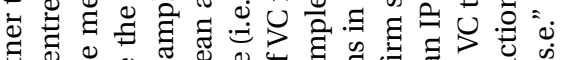

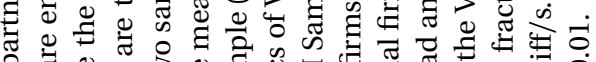
O

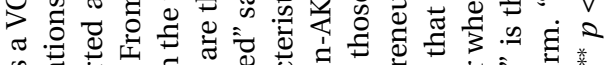

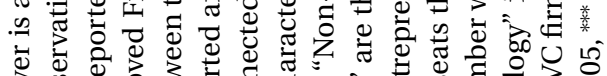

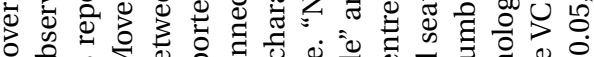

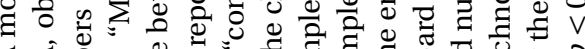

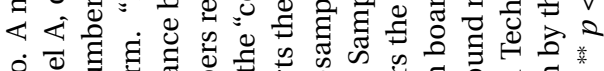

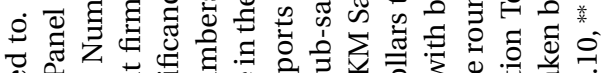

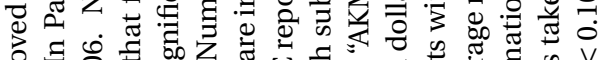

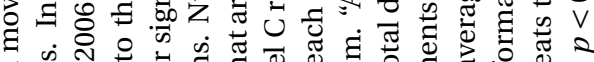

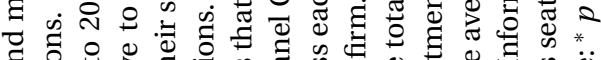
记

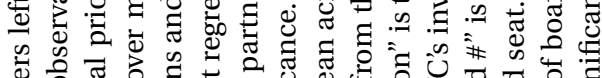

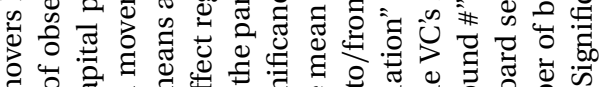
ठั

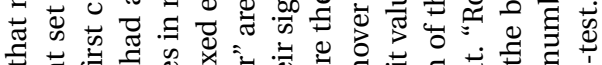

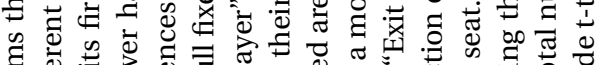

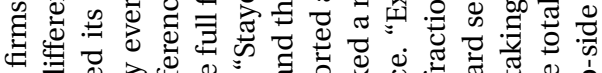

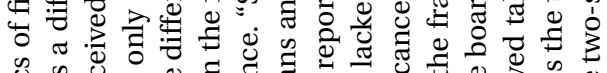

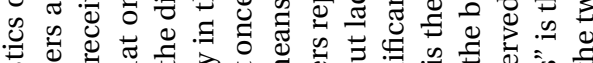

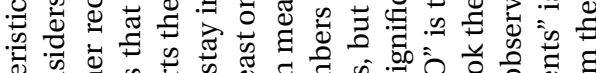
क्षे

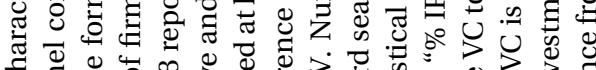

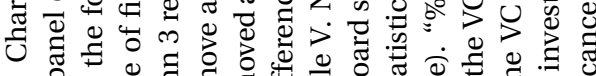
论

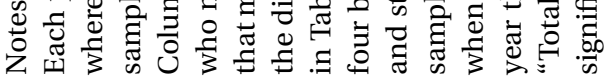

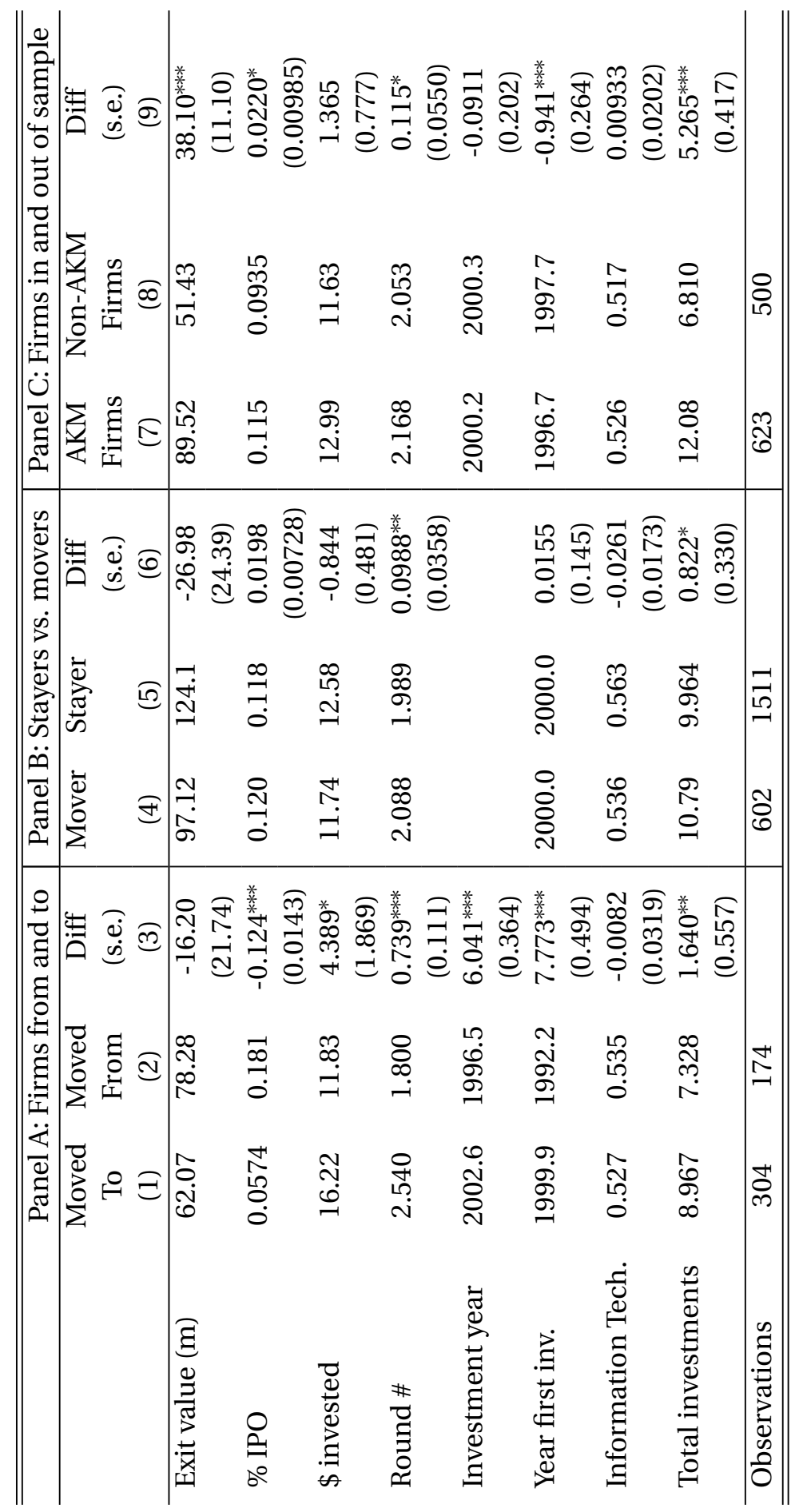


Notes: Three-way fixed effects regressions using the method detailed in Abowd, Creecy and Kramarz (2002) and Abowd, Kramarz and Margolis (1999) to estimate both the VC firm and VC partner fixed effects. Estimation implemented using the Stata code "felsdvreg" as described in Cornelissen (2008). The unit of observation is the VC partner, board seat and entrepreneurial firm outcome. All regressions use the log of exit valuation. "Similar" starts with movers who moved to a firm that was in the lower $50 \%$ of the difference in new vs. previous firm performance. "Different" starts with the movers who moved to a firm that was in the top $50 \%$ of the difference in new vs. previous firm performance. The connected group is constructed after restricting to this set of movers. "Moved down" includes movers whose new firm's IPO rate was higher than their previous firm's IPO rate as of the move. "Moved up" is the same, but when the new firm has the same or better historical performance. If a mover moves to a new firm or forms a new firm, the firm and mover is excluded from these regressions. All other variables as defined in Table V Robust standard errors clustered at the VC firm are reported in parentheses. Significance: $* p<0.10$, ** $p<0.05,{ }^{* * *} p<0.01$.

\begin{tabular}{|c|c|c|c|c|}
\hline & $\begin{array}{c}\text { Moved down } \\
\text { (1) }\end{array}$ & $\begin{array}{l}\text { Moved up } \\
\text { (2) }\end{array}$ & $\begin{array}{c}\text { Similar } \\
(3)\end{array}$ & $\begin{array}{l}\text { Different } \\
(4)\end{array}$ \\
\hline \multicolumn{5}{|c|}{ Relative importance of estimates in $R^{2} . \%$ 's are fraction $R^{2}$ explained by covariate. } \\
\hline \multirow{2}{*}{$\begin{array}{l}\frac{\operatorname{cov}(Y, P a r t n e r F E)}{\operatorname{var}(Y)} \\
\frac{\operatorname{cov}(Y, V C F E)}{\operatorname{var}(Y)}\end{array}$} & $0.12(50 \%)$ & $0.10(43 \%)$ & $0.14(70 \%)$ & $0.11(47 \%)$ \\
\hline & $0.02(8 \%)$ & $0.04(17 \%)$ & $<0.001(0 \%)$ & $0.02(9 \%)$ \\
\hline \multicolumn{5}{|l|}{ F-test on FE (p-value) } \\
\hline VC Partner FE & $<0.01$ & 0.01 & $<0.01$ & $<0.01$ \\
\hline VC Firm FE & 0.72 & 0.51 & 0.57 & 0.68 \\
\hline \multirow[t]{2}{*}{ Round \# (log) } & $0.335^{* * *}$ & $0.359^{* * *}$ & $0.366^{* * *}$ & $0.277^{* * *}$ \\
\hline & $(0.0572)$ & $(0.0636)$ & $(0.0587)$ & $(0.0588)$ \\
\hline \multirow[t]{2}{*}{ Dollars invested (log) } & $0.261^{* * *}$ & $0.281^{* * *}$ & $0.286^{* * *}$ & $0.246^{* * *}$ \\
\hline & $(0.0330)$ & $(0.0390)$ & $(0.0383)$ & $(0.0350)$ \\
\hline \multirow[t]{2}{*}{ Partner experience yrs. (log) } & -0.0952 & -0.0181 & -0.0533 & -0.0232 \\
\hline & $(0.115)$ & $(0.115)$ & $(0.113)$ & $(0.119)$ \\
\hline \multirow[t]{2}{*}{ VC experience yrs. (log) } & -0.0251 & -0.124 & -0.0921 & -0.0670 \\
\hline & $(0.0860)$ & $(0.0916)$ & $(0.0892)$ & $(0.0848)$ \\
\hline \multirow[t]{2}{*}{ Fund sequence (log) } & 0.104 & 0.261 & 0.159 & 0.241 \\
\hline & $(0.175)$ & $(0.217)$ & $(0.193)$ & $(0.208)$ \\
\hline Observations & 13163 & 10213 & 11813 & 10498 \\
\hline$R^{2}$ & .25 & .24 & .24 & .25 \\
\hline \# Movers & 254 & 155 & 218 & 191 \\
\hline \# Stayers & 1134 & 878 & 1040 & 891 \\
\hline \# VC Firms & 311 & 240 & 288 & 261 \\
\hline Year FE? & $\mathrm{Y}$ & $\mathrm{Y}$ & $\mathrm{Y}$ & $\mathrm{Y}$ \\
\hline Industry FE? & $\mathrm{N}$ & $\mathrm{N}$ & $\mathrm{N}$ & $\mathrm{N}$ \\
\hline
\end{tabular}

